Marquette University Law School

Marquette Law Scholarly Commons

Faculty Publications

Faculty Scholarship

$1-1-2010$

\title{
The Domestication of International Criminal Law: A Proposal for Expanding the International Criminal Court's Sphere of Influence
}

Lisa J. Laplante

Marquette UniversityLaw School, llaplante@nesl.edu

Follow this and additional works at: http://scholarship.law.marquette.edu/facpub

Part of the Law Commons

Publication Information

Lisa J. Laplante, The Domestication of International Criminal Law: A Proposal for Expanding the International Criminal Court's Sphere of Influence, 43 J. Marshall L. Rev. 635 (2010)

\section{Repository Citation}

Laplante, Lisa J., "The Domestication of International Criminal Law: A Proposal for Expanding the International Criminal Court's Sphere of Influence" (2010). Faculty Publications. Paper 146.

http://scholarship.law.marquette.edu/facpub/146 


\title{
THE DOMESTICATION OF INTERNATIONAL CRIMINAL LAW: A PROPOSAL FOR EXPANDING THE INTERNATIONAL CRIMINAL COURT'S SPHERE OF INFLUENCE
}

\author{
LISA J. LAPLANTE*
}

\section{INTRODUCTION}

How do we evaluate the effectiveness of the International Criminal Court (ICC)? Such an inquiry may focus on the number of arrest warrants, indictments, and prosecutions credited to the Court since it opened its doors at The Hague after the entry into force of the Rome Statute in 2002. ${ }^{1}$ However, this Article proposes broader criteria for assessing the impact of the ICC, arguing that the true test of the ICC's success will depend on whether it helps to combat impunity and deter future human rights atrocities across the globe.

This measurement embodies the overarching aim that motivated the establishment of the ICC: "to put an end to impunity for the perpetrators of [the most serious] crimes and thus to contribute to the prevention of such crimes."2 Certainly, the "millions of children, women and men [that] have been victims of unimaginable atrocities that deeply shock the conscience of humanity" motivated the many academics and advocates who spent years dedicated to realizing the dream of creating an international forum to assure that the "enemies of mankind" would not escape justice. ${ }^{3}$

However, it is completely unrealistic that the ICC can achieve

* Visiting Assistant Professor, Marquette University Law School. I owe gratitude to Annalyn Kuen, Francisco Saa, and Elise Harris for their excellent assistance with research and editing. I would also like to thank Gregory Gordon and Ken Gallant for their thoughtful comments of preliminary drafts of this Article.

1. Tim McCormack, The Contribution of the International Criminal Court to Increasing Respect for International Humanitarian Law, 27 U. TASMANIA L. REV. 22, 24 (2008) (acknowledging the difficulty of assessing the contribution of the ICC on helping to increase respect for humanitarian law even before first trial).

2. Rome Statute of the International Criminal Court pmb., July 17, 1998, 2187 U.N.T.S. 90 [hereinafter Rome Statute].

3. Id. 
this ambitious goal on its own. On average, it is estimated to have the resources and capacity to handle only two or three trials a year, and the handful of cases pending in its docket will take years to conclude. ${ }^{4}$ Additionally, as a treaty-based international organization, it only enjoys jurisdiction to hear cases committed in the territory of States Parties, or those referred by the Security Council through its exceptional Chapter VII power in situations that threaten international peace and security. ${ }^{5}$ Finally, the Court's Office of the Prosecutor (OTP) can only focus on criminal acts that occurred after the Rome Treaty entered into force in $2002 .{ }^{6}$ In effect, these restrictions mean that depending on the ICC to bring many of the world's most serious offenders to justice would be a gift to impunity. ${ }^{7}$ This reality underscores the imperative of assuring effective domestic prosecutions for the most serious international crimes like genocide, war crimes, and crimes against humanity. ${ }^{8}$

Not coincidentally, scholars and even the OTP have interpreted the concept of "complementarity" to not only assure sovereign prerogative in prosecuting serious offenders but to require so in light of the fact that the Rome Statute embodies the principle of erga omnes, thus places a well recognized obligation on all nations to prosecute crimes that violate jus cogen norms. ${ }^{9}$ This interpretation finds its moorings in the principle of complementarity, which sprung from the determination of negotiators of the Rome Statute who sought to guard domestic jurisdiction from international intrusion, but when later flipped on its head came to mean that this sovereign prerogative is in fact a legal duty. In effect, the ICC exists as a constant reminder of states' responsibility to combat impunity.

The value of this focus has become more apparent over the last decade, as seen through the evolution of scholarly writing on the issue of complementarity. In the early stages of the ICC's development, academics defined the relationship between States Parties and the Court in narrow and protective terms shaped largely by the strict guidelines to admissibility found in Article

4. William W. Burke-White, Proactive Complementarity: The International Criminal Court and National Courts in the Rome System of International Justice, 49 HARV. INT'L L.J. 53, 54 (2008).

5. Rome Statute, supra note 2, art. 13.

6. Id. art. 11 .

7. Jahn K. Kleffner, The Impact of Complementarity on National Implementation of Substantive International Criminal Law, 1 J. INT'L CRIM. JUST. 86, 93 (2003) (noting, "A great majority [would] profit from impunity and no significant deterrent effect would unfold").

8. The Rome Statute limits the ICC's jurisdiction to these three crimes. Rome Statute, supra note 2, arts. 5-7.

9. M. Cherif Bassiouni, International Crimes: Jus Cogens and Obligatio Erga Omnes, 59 LAW \& CONTEMP. PROBS. 63, 66 (1996). 
17. ${ }^{10}$ In this situation, the ICC was seen to wield both a "carrot and stick," encouraging nations to harmonize their national criminal justice aperture to assure effective national trials and avoid the political cost of ICC involvement. ${ }^{11}$ However, a recent trend sees scholars recognizing the Court's long-term success as, in fact, depending on this alignment of domestic standards with international norms, leading to proposals that the internationalnational collaboration be less passive and more positive. ${ }^{12}$ Here, complementarity has come to be a more dynamic concept. For example, Professor William Burke-White presents the idea of "proactive complementarity" to allow the ICC to engage more actively in a monitor-like function with States Parties undertaking criminal investigations, even providing outreach, technical assistance, and guidance. ${ }^{13}$

Yet, scholars proposing a more positive spin on the complementarity principle take as their starting point the temporal and geographic treaty restrictions imposed by the Rome Statute. The practical result being that international-national collaboration would only occur with regard to trials involving criminal acts that occurred after 2002, that is from the time the Rome Statute entered into force. ${ }^{14}$ Moreover, complementarity continues to be narrowly understood only in terms of admissibility of cases via Article 17 (which has no mention of the term complementarity). This orientation leads to two notable consequences that undermine the overall effectiveness of the ICC in attaining its broader mission. First, the ICC will remain completely removed from many local efforts to harmonize national systems with international norms. At the same time, the ICC will also be removed from many important domestic criminal proceedings, although these trials involve a significant number of the world's worst offenders whose trials constitute important contributions to international jurisprudence that directly impacts the ICC's own work to assure uniformity in prosecutions of international crimes. ${ }^{15}$ In the end, the arbitrary delineation of

10. Darryl Robinson, The Mysteriousness of Complementarity, 21 CRIM. L.F. (forthcoming Feb. 2010), available at http://papers.ssrn.com/sol3/papers.cfm? abstract_1559403.

11. Kleffner, supra note 7 , at 87.

12. See discussion infra Part IV (exploring the social and legal implications of a more proactive complementarity as seen in the case of Peru).

13. Burke-White, supra note 4, at 54.

14. See Rome Statute, supra note 2, art. 11 (stating that the jurisdiction of the Court only applies to crimes that occur after the Rome Statute comes into force). See also Philippe Kirsch, Applying the Principles of Nuremberg in the International Criminal Court, 6 WASH. U. GlOBAL STUD. L. REV. 501, 506 (2007) (referring to this temporal restriction as a "caveat").

15. See discussion infra Part III (presenting a genealogy of the concept of "complementarity" to reveal the evolution of the term from the time of the 
post-2000 crimes amounts to a missed opportunity for the ICC to help oversee the achievement of the international community's goals of ending impunity and preventing future atrocities.

Secondly, this strict interpretation of the ICC's mandate also means that it will miss the opportunity to offer the subtle type of international support that can often create a "moral suasion" that helps assure the momentum of transitional justice schemes. Only recently are scholars beginning to examine the intersection between the ICC and the field of transitional justice, which concerns itself with the phenomena of countries adopting various judicial and non-judicial means of redressing past episodes of violent conflict and state repression. Importantly, transitional justice projects usually seeks to address the corruption and debilitation of their national judiciaries-whose defects led to the breakdown of the rule of law and the commission of international crimes that fall into the ambit of crimes that the ICC seeks to address and will ultimately serve the ICC's overarching mission to end impunity. In particular, transitional justice epitomizes the essence of complementarity's aim to decentralize accountability, while at the same time promoting reform efforts that can spell improved chances for future international-national collaboration with the ICC. Yet, when such transitions concern historical periods preceding the entry into force of the Rome Statute, any liaison with the ICC becomes foreclosed due to the temporal restrictions of current interpretations of the ICC's jurisdiction.

In response, I propose a widening of the concept of proactive complementarity to include engagement with States Parties, even if it regards matters that technically fall outside the jurisdiction ratione temporis found in the Rome Statute's Article 11 and admissibility requirements of Article 17. I discuss the possibilities of this proposal through the case study of Peru which undertook a transitional justice process in 2001, which eventually included a truth commission, criminal trials, and significant institutional reform efforts. Indeed, despite the fact that this process included one of the few times that a wholly domestic court prosecuted a former head of state for conduct that constitutes international crimes, the ICC had no engagement with Peru during the various stages of the criminal trial of former President Alberto Fujimori (1990-2000). Arguably, the ICC may have exerted important influence during this process: First, it could have lent political support as the government sought to harmonize the domestic criminal justice system to the standards of the Rome Statute, but has encountered political opposition leading to a prolonged delay in incorporating these norms. Second, the ICC could have assumed a more active presence with regard to the historic human rights

Rome Statute's negotiations until the present). 
trials of Fujimori, whose charges related to acts occurring before 2002. Notably, neither of these situations could have technically triggered the ICC's Article 17 jurisdiction, but as I will explain, still merit the Court's attention for reasons related to the ICC's overall mission. I will examines ways that the Court could have taken a more proactive role in supporting the Peruvian transitional justice process, and discuss the concrete advantages that this involvement could have had to promote the ICC's mandate to assure the non-repetition of serious international crimes.

To offer context for the discussion of the case study of Peru, Part II examines the underlying theory of deterrence for combating impunity that motivated the international community to create the ICC, and how this aim largely shapes not only the mission of the ICC but the criteria that should be used to evaluate its success. Part III presents a genealogy of the concept of "complementarity" to reveal the evolution of the term from the time of the Rome Statute's negotiations until the present.

Early scholarship poses mostly theoretical suppositions and abstract analysis of the ICC's role vis a vis national jurisdictions, perceiving the origins of complementarity as a protective measure that uses restrictive jurisdictional rules to protect against the intrusion of the ICC in domestic juridical affairs. After the ICC opened its doors, the scholars began to propose that complementarity evolve as a more fluid concept that could allow the ICC-particularly the $\mathrm{OTP}$ - to play a more proactive role in moving the global community toward a more uniform approach to prosecuting international crimes. However, this literature still assumes that this more positive role would pertain only to situations falling within the ICC's Article 11 and 17 jurisdiction, a starting point that I contest.

In Part IV, I explore the social and legal implications of this limited view of proactive complementarity as seen in the case of Peru. I make suggestions on how the ICC could have played a more involved role in the trial of former Peruvian president Alberto Fujimori as well as in the implementation of domestic law to harmonize with the Rome Statute.

\section{AN INTERnAtional CRIMINAL COURT: DETERRING INTERNATIONAL CRIMES}

A culmination of more than a century of work preceded the entry into force of the Rome Statute that brought the ICC to life in July 2002.16 High aspirations motivated this effort, with the Court representing "the hope of governments from all around the world that the force of international law can restrain the evil impulses

16. Burke-White, supra note 4 , at 58-9. 
that have stained history with the blood of millions of innocent victims." 17 Yet, the idea of an international forum for holding individuals to account for international crimes focused "not simply on the goal of giving particular defendants their deserved punishments, but also on the broader aspirations that international trials will facilitate society-wide transformation by breaking cycles of violence, delegitimizing criminal regimes and fostering peaceful societies rooted in the rule of law."18 This ambitious agenda was even recognized by former United Nations Secretary-General Kofi Annan, who viewed the ICC as offering "new hope for a permanent reduction in the phenomenon of impunity." 19

In essence, these aspirations make deterrence central to the mission of the ICC. ${ }^{20}$ As recognized by the OTP, criminal prosecutions "send an important warning to those individuals who might otherwise continue to resort to violence and criminality as a means of achieving their aims."21 Similarly, former ICC Judge Philippe Kirsch explained to the United Nations General Assembly: "The International Criminal Court was created to break the vicious cycle of crimes, impunity and conflict. It was set up to contribute to justice and the prevention of crimes, and thereby to peace and security ... [and] to guarantee lasting respect for and the enforcement of international justice." 22 In fact, when the plenipotentiaries voted 120 to 7 on the evening of July 17, 1998, to approve the Rome Statute, it was believed that "the mere existence of such a court would help end impunity for major crimes against international law, and would act as a permanent deterrent to despots and tyrants." 23

17. Lieutenant Colonel Michael A. Newton, Comparative Complementarity: Domestic Jurisdiction Consistent with the Rome Statute of the International Criminal Court, 167 MIL. L. REV. 20, 23 (2001).

18. Alexander K.A. Greenawalt, Complementarity in Crisis: Uganda, Alternative Justice, and the International Criminal Court, 50 VA. J. INT'L L. 107, 128 (2009) (citing RUTI G TEITEL, TRANSITIONAL JUSTICE 28 (2000)).

19. The Secretary-General, Report of the Secretary-General on the Rule of Law and Transitional Justice in Conflict and Post Conflict Societies, 1, delivered to the Security Council and the General Assembly, U.N. Doc. S/2004/616 (Aug. 23, 1994).

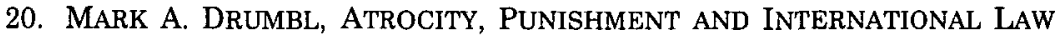
16 (2007).

21. ICC-OTP, Fourth Report of the International Criminal Court to the U.N. Security Council Pursuant to UNSCR 1593, 10 ICC-OTP (Dec. 14, 2006).

22. Jessica Almqvist, Complementarity and Human Rights: A Litmus Test for the International Criminal Court, 30 LOY. L.A. INT'L \& COMP. L. REV. 335, 354 (2008) (citing Philippe Kirsch, Address to the U.N. General Assembly, U.N. Doc. 3 (Nov. 1, 2007)).

23. Allen J. Dickerson, Who's in Charge Here? International Criminal Court Complementarity and the Commander's Role in the Courts-Martial, 54 NAVAL L. REV. 141, 141 (2007). 
In theory, this "deterrence function" assumes that potential violators will refrain from committing international crimes if they perceive an increased likelihood of punishment. ${ }^{24}$ Yet, in reality, an offender has "about as much chance of being prosecuted as winning the lottery."25 Practical limits-limited personnel, funding, and time-diminish the ICC's ability to assure high rates of prosecution and punishment to bolster the perception of its power to hold perpetrators to account.. ${ }^{26}$ Indeed, one of the most common criticisms of the field of international criminal law is the difficulty of enforcing international standards and non-compliance with international criminal law standards, which results in the stark contrast between "law-in-the-books" and "law-in-practice."27 The practical result is impunity. However, blaming this situation on the ICC is misplaced given that the origin of this failing is caused largely by state inaction. ${ }^{28}$ Arguably, it is this very inaction at the local level that led the international community to form an international tribunal to begin strengthening the general global commitment to prosecuting international crimes. This effort grows out of the consensus that deterrence occurs when there is credible threat of punishment. ${ }^{29}$

Yet, importantly, negotiators of the Rome Statute did not

24. See generally JoHANNES ANDENAES, PUNISHMENT AND DETERRENCE (1974) (offering a traditional explanation of the logic of deterrence).

25. Michael L. Smidt, The International Criminal Court: An Effective Means of Deterrence?, 167 MIL. L. REV. 156, 188 (2001).

26. That said, it seems evident through recent cases that the OTP's perceived interest in cases that do fall within its jurisdiction can greatly contribute to deterrence. See, e.g., Mike McGovern, Proleptic Justice: The Threat of Investigation as a Deterrent to Human Rights Abuses in Côte d'Ivoire, in MIRRORS OF JUSTICE: LAW AND POWER IN THE POST-COLD WAR ERA 79-80 (Kamari Maxine Clarke \& Mark Goodale eds., 2009) (describing how the ICC "remained seized" of the situation in Côte d'Ivoire resulting in rebels reigning in their fighters so as to avoid future prosecution). Yet, this direct attention on these settings suggests that countries that do not have situations that could trigger the ICC attention will not have that "perceived" risk that contributes to risk aversion and changed behavior.

27. Immi Tallgren, Completing the "International Criminal Order": The Rhetoric of International Repression and the Notion of Complementarity in the Draft Statute for an International Criminal Court, 67 NORDIC J. INT'L L. 107, 108 (1998).

28. Almqvist, supra note 22, at 352 .

29. Tom Syring, Truth v. Justice: A Tale of Two Cities?, 12 INT'L LEGAL THEORY 143, 204 (2006). A growing body of scholarship questions whether international courts effectively deter future crimes. See generally David Wippman, Atrocities, Deterrence, and the Limits of International Justice, 23 FORDHAM INT'L L.J. 473 (1999); Jan Klabbers, Just Revenge? The Deterrence Argument in International Criminal Law, 12 FINNISH Y.B. INT'L L. 249, 25153 (2001); Payam Akhavan, Beyond Impunity: Can International Criminal Justice Deter Future Atrocities?, 95 AM. J. INT'L L. 7, 12 (2001); Julian Ku \& Jide Nzelibe, Do International Criminal Tribunals Deter or Exacerbate Humanitarian Atrocities?, 84 WASH. U. L. REV. 777 (2007). 
seek to create the ICC to replace national jurisdictions, but rather to help begin to assure the more effective and efficient functioning of national criminal prosecutions. Surely, deterrence works optimally at the local level where civil and military leaders, the primary subjects of the ICC's jurisdiction, feel constrained by the precedent of their predecessors being held criminally accountable. As will be discussed in the following section, this model of international-national collaboration implies a broader interpretation of the principle of complementarity.

\section{The EVOlving DeFINITION OF COMPLEMENTARITY: ESTABLISHING THE CONTOURS OF THE INTERNATIONAL- NATIONAL RELATIONSHIP}

The meaning and scope of the term "complementarity" has inspired much debate over the years despite the fact that the principle forms a "cornerstone" of the ICC. ${ }^{30}$ While the ICC negotiation process coined this new term, it did not include an explicit reference to it or its definition in the articles of the Rome Statute but rather emphasizes in the preamble that "the International Criminal Court established under this Statute shall be complementary to national criminal jurisdiction." ${ }^{1}$ Moreover, little meaning can be derived from the travaux preparatoires "because the term is meaningless in the abstract and it was often dressed up to mean different things by different states." 32 Scholars have hammered away at an agreed upon construction of defining complementarity, often guided by the belief that this "intellectually simple concept . . . masks the deep philosophical and political difficulties that the International criminal court must overcome if it is ever to become a functioning institution." 33 Certainly, this yearning for clarity continues to drive the ICC scholarship that seeks to define the contours of complementarity guided by the notion that "[a] unified theoretical framework to describe and give effect to complementarity is crucial to guide the ICC." 34

30. Benjamin Perrin, Making Sense of Complementarity: The Relationship Between the International Criminal Court and National Jurisdictions, 18 SRI LANKA J. INT'L L. 301 (2006).

31. Rome Statute, supra note 2, pmbl. This section of the Rome Statute and its reference to complemetarity has been further examined. See Tallgren, Completing the "International Criminal Order", supra note 27, at 120 (explaining that the first reference to complementarity can be found in 1994 draft report of International Law Commission's draft statute).

32. Perrin, supra note 30.

33. Newton, supra note 17 , at 72 .

34. Perrin, supra note 30 , at 310 . 


\section{A. Framing Complementarity in the Negative: Restrictive Jurisdiction and $a$ Watchdog International Court}

Scholars initially responded to this lacuna of meaning by construing a definition of complementarity through traditional treaty interpretation methods. ${ }^{35}$ Specifically, complementarity was understood with reference to Article 17, which regulates admissibility within the restrictions of paragraph 10 of the Rome Statute preamble (emphasizing that international jurisdiction shall "complement" national jurisdiction). ${ }^{36}$ Significantly, the text sets up the task of determining admissibility in the negative, directing the ICC to proceed with criminal investigations only where a state is "is unwilling or unable genuinely to carry out the investigation or prosecution." 37 This more streamlined vision of the relationship between international and national legal systems creates a high bar to admission, and a "relatively unambitious vision of the Court." 38 At essence, Article 17 serves as a "barrier to jurisdiction" 39 with the ICC intervention deemed as "exceptional," thus promoting the "unconditional presumption of national omnipotence in the field of criminal law." 40

Certainly, this restrictive jurisdiction-driven interpretation of complementarity echoes the contentious debates during the negotiations of the Rome Statute that "raw politics" made complementarity an "organizing principle" to institutionalize a protectionist stance toward an international penal court.41 This struggle of sorts revealed that "most States are terribly jealous about their powers of criminal prosecution. They perceive these powers as linked to the very concept of sovereignty." 42 This Hobbesian approach preserves the police power prerogative of states, whose legitimate coercive power is best exemplified through criminal prosecutions. ${ }^{43}$ As recognized by Brownlie, "the

35. Id. at 304 (citing to the Vienna Convention on the Law of Treaties to argue that treaty provisions must be read in light of treaty preambles).

36. Id.

37. Rome Statute, supra note 2, art. 17(a). For a more in depth discussion of the mechanisms of admissibility, see Héctor Olásolo, The Triggering Procedure of the International Criminal Court, Procedural Treatment of the Principle of Complementarity, and the Role of Office of the Prosecutor, 5 INT'L CRIM. L. REV. 121 (2005).

38. Dickerson, supra note 23, at 152.

39. Markus Benzing, The Complementarity Regime of the International Criminal Court: International Criminal Justice between State Sovereignty and the Fight Against Impunity, 7 MAX PLANCK Y.B. U.N. L. 591, 594 (2003).

40. Tallgren, Completing the "International Criminal Order", supra note 27, at 124 .

41. Newton, supra note 17 , at 47 .

42. Mohamed M. El Zeidy, The Principle of Complementarity: A New Machinery to Implement International Criminal Law, 23 MICH. J. INT'L L. 869, 878 (2001).

43. ThOMAS HobBes, The LeViathan (1660). For discussion of the 
exercise of criminal jurisdiction can indeed be said to be a central aspect of sovereignty itself." 44

Thus, unlike the international tribunals of the former Yugoslavia and Rwanda which enjoy primacy over national courts, the ICC embodies "an enforcement regime based on overlapping power between territorial sovereigns (states) and non-territorial sovereigns (the international community as a whole, represented by the ICC prosecutor)." 45 Here, the principle of complementarity strikes a "delicate balance" where sovereigns are never subordinate to the authority of the ICC. ${ }^{46}$ This deference to national jurisdiction also shapes the view of the ICC's appropriate role in the global fight against impunity. The Court is meant to "supplement" and not "supplant" domestic enforcement of international norms. ${ }^{47}$ As a former ICC judge explained to the Council on Foreign Relations in New York, "It is only in extreme cases that the international community should intervene. Normally there should be no reason to intervene. Normally there should be no reason for international tribunals . . the business of the court is not to second-guess domestic proceedings. The ICC is not after prosecution." 48

Yet, often the ICC's role came to have an almost menacing tone: "The wonder of the exhaustion process is that it does not require the ICC to brandish its authority in order to achieve integration of Rome Statute components into the national law[t] he Court can stay on the sidelines while the national courts feel the burden of the Court's watchful eye exhorting the State to do its best." 49 Bruce Broomhall suggests that the ICC would "spur" on national prosecutions in order to avoid "adverse attention, the diplomatic entanglements, the duty to cooperate and other consequences of ICC activity have a real incentive to take actions against crimes under the [Rome] statute." ${ }^{50}$ However, once the ICC actually began to operate and take cases, the aspirations for a policeman-like role began to wane and give way to a more benevolent vision of the proper role of the Court. Arguably, this

restrictive approach, see generally Tallgren, Completing the "International Criminal Order", supra note 27, at 128.

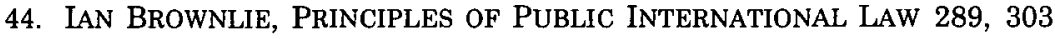
(Oxford Univ. Press, 5th ed. 1998) (1966).

45. Newton, supra note 17, at 39; El Zeidy, supra note 42, at 896.

46. Benzing, supra note 39 , at 600 .

47. Newton, supra note 17 , at 26.

48. Perrin, supra note 30 , at 316.

49. Ada Sheng, Analyzing the International Criminal Court Complementarity Principle Through a Federal Court Lens, 13 ILSA J. INT'L \& CoMP. L. 413, 424 (2006).

50. BRUCE BROOMHALL, INTERNATIONAL JUSTICE AND THE INTERNATIONAL CRIMINAL COURT: BETWEEN SOVEREIGNTY AND THE RULE OF LAW 84, 87 (2003). 
shift responded to the reality that the mission of the ICC related directly to the phenomena of increasing effective national prosecutions.

\section{B. The ICC's More Benevolent, Albeit Passive, Role in Encouraging National Prosecutions}

Although operating only in the last few years, the ICC has faced certain realities that were perhaps less clear when the idea of an international penal court existed only as a theoretical goal. Most compelling is the fact that the "ICC cannot prosecute all crimes committed. It is entirely necessary to obtain effective prosecution through the national level. Due to its restricted capacity and resources the ICC can only deal with limited cases and has to rely on the direct enforcement through State parties."51 Otherwise, the ICC would need to become a "court of first (and only) instance," completely contrary to the vision that inspired its development. ${ }^{52}$

Certainly, states are better positioned with regard to access to evidence and witnesses, experience with administering laws, operating without language barriers, and other advantages that ease some of the logistical issues associated with prosecuting crimes far from the scene of the crime. ${ }^{53}$ Perhaps more importantly, national proceedings enjoy greater legitimacy among local populations and have "the greatest impact in the eyes of society most immediately interested in them." 54 Returning to the idea of "perceived" justice, localizing justice not only satisfies the justice needs of victims and affected populations but also contributes to deterrence since it raises the chances of prosecution for future offenders. ${ }^{55}$

As early as 2003, an OTP policy paper concluded, "national investigations and prosecutions, where they can properly be undertaken, will normally be the most effective and efficient means of bringing offenders to justice." 56 Deference to national jurisdiction is thus not simply a "concession to realpolitick but a substantive and sound operating rule that recognizes that trials closer to the scene of events at issue have inherent practical as

51. Lijun Yang, On the Principle of Complementarity in the Rome Statute of the International Criminal Court, 4 CHINESE J. INT'L L. 121, 125 (2005).

52. Kleffner, supra note 7 , at 93.

53. BROOMHALL, supra note 50 , at 84 .

54. Id.

55. Olugbuo offers the aphorism that "justice should not only be done, but should manifestly and undoubtedly be seen to be done." Benson Chinedu Olugbuo, Implementing the International Criminal Court Treaty in Africa, in MIRRORS OF JUSTICE: LAW AND POWER IN THE POST-COLD WAR ERA 106 (Kamari Maxine Clarke \& Mark Goodale eds., 2009).

56. ICC-OTP, Paper on Some Policy Issues before the Office of the Prosecutor, at 2 (Sept. 2003). 
well as expressive value" 57 This more commonsense understanding of national jurisdiction also allows the question to shift from whether the ICC will "trample" sovereign prerogative toward whether it can "coexist in a constructive and beneficial relationship with all nations." 58 Thus, the complementary regime came to signify a international-national role where the ICC "encourage[d] states to exercise their jurisdiction and thus make the system of international criminal law enforcement more effective" 59 with the aim of increasing "the number of judicial fora where cases could occur." 60 Certainly, this approach makes better sense considering that " $[\mathrm{m}]$ ost violators of international law have been tried in domestic forums," 61 a trend unlikely to end given the restrictive rules of ICC admissibility. ${ }^{62}$

Yet, how does this orientation shape the most appropriate role for the ICC? If its work is confined only to prosecuting the handful of cases that squeeze through its demanding jurisdictional test, then in the end it will play a rather limited role in the international quest to end impunity. Alternatively, taking a more active role with regard to decentralizing prosecutions would give the ICC a better chance at combating impunity. Indeed, the OTP began to publicly proclaim indications of this evolving understanding of complementarity. In September 2006, the OTP publicized its Prosecutorial Strategy where it declared to have "adopted a positive approach to complementarity, meaning that it encourages national proceedings where possible; relies on national and international networks; and participates in a system of international cooperation." 63 In fact, the OTP began to apply a new test for measuring its success, explaining it would not be based on how many cases reach the ICC but "on the contrary, the absence of trials before this Court, as a consequence of the regular functioning of national institutions, would be a major success."64

Arguably, this "emerging positive approach" not only reflected a practical and sensible assessment of the ICC's appropriate role, but also opened the door for more progressive proposals for what this role might look like. In some respects, this shift in the vision of the ICC's appropriate role reflects the fallacy of earlier beliefs that "the mere existence of the ICC may do much to encourage

57. José E. Alvarez, The New Dispute Settlers: (Half) Truths and Consequences, 38 TEX. INT'L L.J. 405 (2003).

58. Newton, supra note 17 , at 27.

59. Benzing, supra note 39 , at 596.

60. Burke-White, supra note 4 , at 73 .

61. El Zeidy, supra note 42 , at 870 .

62. Newton, supra note 17 , at 37.

63. Almqvist, supra note 22, at 347-48.

64. ICC-OTP, Statement by Luis Moreno-Ocampo, Prosecutor of the International Criminal Court at the Ceremony for the Solemn Undertaking of the Chief Prosecutor of the International Criminal Court (June 16, 2003). 
genuine national proceedings," with the implicit threat of intervention being enough to motivate state action. ${ }^{65}$ Instead, it has become more apparent that the ICC, and in particular the OTP, might need to use more hands-on types of persuasion and leverage, that "could range from diplomatic communications with governments to the provision of assistance in undertaking prosecutions." 66

\section{The Proactive Complementarity Role: Activating the ICC to Exert Positive Influence}

Charting the broadening concept of complementarity schemes, Carsten Stahn notes that "the nuances and limits of a 'positive' reading of complementarity are still unclear."67 Yet, a new direction in the ICC scholarship reveals an undeniable desire to see the ICC play a more active role in assuring successful national prosecutions for international crimes. For example, Professor William Burke-White proposes the new framework of "positive complementarity" for the ICC's role in assisting national judiciaries to become able to prosecute international crimes thus coming closer to achieving "the statutory goal of ending impunity" despite limited resources. ${ }^{68}$ Arguably, an investment of resources up front would also minimize resources over the long term as national systems become more self-sufficient.

Burke-White's proposal comes as a warning, explaining that "[t]he Court's failure to use consciously its power to catalyze national prosecutions is a potentially dangerous mistake .. . neglecting the ICC's political and legal power to encourage national prosecutions of international crimes may well undermine the institution's best hope to meet expectations and enhance accountability."69 He further expands,

To avoid either a real or perceived failure, new strategies must be developed to end impunity and to contribute to at least some of the broader expectations of the Court. Such strategies must fit within the ICC's legal, political, and financial limitations and must help shift the burden of prosecution back to states. By effectively harnessing national jurisdictions in the pursuit of accountability, the policy of proactive complementarity advocated here has the potential to make a considerable contribution toward ending impunity without the need for a substantial expansion of the Court's resources and capacity. Likewise, such an approach would help further the Court's other goals, such as national reconciliation and

65. Burke-White, supra note 4 , at 71 .

66. Id.

67. Carsten Stahn, Complementarity: A Tale of Two Notions, 19 CRIM. L.F. 87 (2008).

68. Burke-White, supra note 4 , at 54 .

69. Id. at 56 . 
judicial reconstruction. ${ }^{70}$

Burke-White builds on his earlier work that promotes a vision of the "Rome system of justice" where a policy of proactive complementarity uses a "full range of legal and political levers to influence available to the court to encourage and at times even assist national governments in prosecuting international crimes themselves." 71 This intervention may include anything from "training of officials, the provision of resources, or assistance with investigations."72

Interestingly, Burke-White justifies this expansive role through interpreting the Rome Statute to do "far more than merely define the limits of the Court's power" but instead reaffirms its role as "a 'catalyst' to help states fulfill their preexisting treaty obligations." " In this way, complementarity is a "newly minted phrase that builds on the well-established practice of nations enforcing international law." 74 In effect, the Rome Statute only "reinforces a central role of national criminal justice institutions in that it does not merely reiterate a general competence of states to exercise criminal jurisdiction over such crimes, but stipulates that it is a duty of states to do so."75 International law has long recognized the erga omnes obligation of states to enforce international criminal law. ${ }^{76}$ In fact, the Rome Statute preamble explicitly refers to this fundamental idea, "[r]ecalling that it is the duty of every State to exercise its criminal jurisdiction over those responsible for international crimes." 77 The Preamble's declaration indicates that the duty to prosecute precedes the coming into force of the Rome Statute ${ }^{78}$ since it arises out of treaty and customary law. ${ }^{79}$

Through this lens, complementarity no longer means that sovereigns have a discretionary prerogative to prosecution, but

70. Id. at 67 .

71. Id. at 56. See also William W. Burke-White, A Community of Courts: Toward a System of International Criminal Law Enforcement, 24 MICH. J. INT'L L. 1, 75 (2002) [hereinafter Burke-White, A Community of Courts] (arguing that national courts are the "front line" of enforcing international criminal law in a decentralized manner).

72. Burke-White, supra note 4 , at $92-93$.

73. Id. at 56 (referring to his earlier article, William W. Burke-White, Complementarity in Practice: The International Criminal Court as Part of a System of Multilevel Global Governance in the Democratic Republic of Congo, 18 LEIDEN J. INT'L L. 557 (2005) [hereinafter Burke-White, Complementarity in Practice]).

74. Newton, supra note 17, at 28.

75. Almqvist, supra note 22, at 335 .

76. JORDAN PAUST ET AL., INTERNATIONAL CRIMINAL LAW 15 (Jordan Paust et al. eds., 1996).

77. Rome Statute, supra note 2, pmbl (emphasis added).

78. Benzing, supra note 39 , at 596.

79. Newton, supra note 17 , at 26. 
rather "an implicit restriction" on their state sovereignty to prosecute; a situation that "takes away the possibility for state parties to remain inactive, even under breach of international law in cases where a duty to prosecute exists under other instruments. The principle thus gives effect to, and indeed completes the idea of an effective decentralized prosecution of international crimes." 80 This reasoning arises out of the fact that the crimes of the ICC are "offenses against the law of nations, delicti jus gentium, and by their very nature affect the world community as a whole." 81 Thus, all states carry the international obligation reflected in the concept of aut dedere aut juidcare that places an affirmative duty on them to either extradite or prosecute alleged violators of international crimes. ${ }^{82}$ In the end, it "is the interest of the international community in the effective prosecution of international crimes, the endeavor to put an end to impunity, and the deterrence of the future commission of such crimes."83

The Rome Statute preamble recognizes this internationalnational interdependence in the preamble, stating: "[T] he most serious crimes of concern to the international community as a whole must not go unpunished" and expresses the view "that their effective prosecution must be ensured by taking measures at the national level and by enhancing international cooperation . . .."84 Put in lofty terms, the Rome Statute reflects

the notion that the sovereign nations of the world are joined, not as competitors in the pursuit of sovereign self interest, but as interdependent components of a larger global civil society ... an overdue step towards a uniform system of responsibility designed to 'promote values fundamental to all democratic and peace-loving states.' 85

In effect, the protective aspect of domestic jurisdiction embodied in the Rome system of justice relates to the implicit rational of the whole system: increase international oversight of state compliance with their preexisting duties. ${ }^{86}$ In this way, "[w]hen a state undertakes to investigate and prosecute those

80. Benzing, supra note 39 , at 600 .

81. El Zeidy, supra note 42 , at 946.

82. M. Cherif Bassiouni, CRimes AGainst Humanity in INTERnational CRIMINAL LAW 515 (Martinus Nijhoff ed., 2d ed. 1999) (1992).

83. Benzing, supra note 39 , at 597 (citations and emphasis omitted).

84. Rome Statute, supra note 2.

85. Lieutenant Colonel Michael A. Newton, Comparative Complementarity: Domestic Jurisdiction Consistent with the Rome Statute of the International Criminal Court, 167 MIL. L. REv. 20, 27-8 (2001) (quoting Batram S. Brown, Primacy or Complementarity: Reconciling the Jurisdiction of National Courts and International Tribunals, 23 YALE J. INT'L L. 383, 436 (1998)).

86. Benzing, supra note 39 , at 600 (" $[F]$ or the effective prevention of such crimes and impunity, the international community has to step in to ensure these objectives and retain its credibility in the pursuance of these aims."). 
heinous crimes it does so as an agent, and on behalf of the entire community." 87 Through this international-national arrangement, enforcement of international criminal law through national prosecutions forms the "principal pillar" of assuring the "deterrent effect for the ultimate purpose of putting an end to impunity and preventing the commission of crimes in the future . . ." 88

\section{Limits to the Current Model of a Proactive ICC Role}

Interestingly, despite the fact that the duty to prosecute belongs to all states, and thus all States Parties to the Rome Statute, any positive involvement of the ICC would only occur with regard to situations that would potentially fall within the ICC's ratione temporis jurisdiction set in Article 11. That is, it would focus its attention on a "target state of investigation," which means only country situations involving criminal acts occurring either after 2002 or from the date that a State Party ratifies the Rome Statute. ${ }^{89}$ The result will be that the OTP will proactively engage only with states in which there is a case that could potentially be brought to the international forum, leaving all other States Parties out of the benefit of its engagement.

For example, William-Burke discusses how proactive complementarity would create "opportunities for communication and dialogue between the Court and national governments ... [because] article 15 allows the Prosecutor to seek information from states with respect to communications he receives." $90 \mathrm{He}$ refers to the case of Sudan where the OTP continuously monitored and evaluated the criminal trials of Sudan including multiple missions by OTP officials to Sudan for evaluative purposes. ${ }^{91}$ Yet the case of Sudan came within the ICC's purview through a Security Council referral regarding the situation in Darfur, pursuant to Article 13 of the Rome Statute's jurisdictional rules. Interestingly, Sudan contested the legality of the ICC intervention on the basis of not being a State Party, but technically does fall within the narrow and explicit terms of admission as set by the Rome Statute given the Security Council referral. ${ }^{92}$

Yet the ICC's focus on only those States Parties falling within the strict temporal limits of the Rome Statute runs contrary to the overarching aim of the ICC to combat impunity in collaboration with all nations. In this vein, scholars often appear to overlook the limits imposed by lex scripta, and instead expound the principle that " $[t]$ he legal authority of domestic states to proscribe

87. El Zeidy, supra note 42, at 911.

88. Kleffner, supra note 7, at 93.

89. Burke-White, Complementarity in Practice, supra note 73 , at 559.

90. Burke-White, supra note 4 , at 81 .

91. Id.

92. Almqvist, supra note 22, at 346 . 
and adjudicate cases involving violations of humanitarian law is so firmly rooted in the international legal regime that the Rome Statute makes no distinction between states party and non-states party with respect to complementarity."93 Indeed, the Rome Statute elucidates customary international law that is binding on all states; ultimately states acting pursuant to these universal standards will contribute to the development of international criminal law regardless of whether they are members of the ICC or have cases that fall within its jurisdiction. ${ }^{94}$ Yet in the end it will only be some States Parties that will benefit from the ICC's attention and focus despite the fact that they could impact the development of international criminal law. This omission raises serious concern given that we stand at a very critical stage in the development of not only the substantive and procedural parameters of international criminal law, but also the relationship between the international-national Rome system of justice. As observed by Ruti Teitel:

Contemporary global legalism ... redefines the status and relation of the international to the national legal regimes in two major ways. First, in the contemporary moment, international criminal law is more pervasive, extending beyond the international realm and state borders as well as circumstances of conflict. Second, while international law is more pervasive and has greater reach than before, it is also increasingly defined by its ongoing interstitiality. By interstitiality it is meant here that in the contemporary relation of the international to the national, international criminal law operates not as an exceptional matter associated with extraordinary postwar sovereignty, but instead in a regular permanent way. ${ }^{95}$

Yet an arbitrary delineation risks creating a dual system in which some national trials dealing with international crimes will fall within a sphere of ICC concern and others fall outside of it despite the principle of "interstitiality," which arguably includes a shared collective goal of combating impunity. This delineation could also result in disproportionate emphasis on some regions, and neglect of others. Given this situation, it may be time to reexamine the assumption of jurisdictional limits to the concept of complementarity, with an eye toward expanding the ICC's global influence.

\section{Missed OPPORTUNITIES FOR EXPANDING THE ROME SYSTEM OF JUSTICE}

In the next section, I will explore how the ICC may become

93. Newton, supra note 17 , at 32 .

94. Kleffner, supra note 7, at 111.

95. Ruti Teitel, Law and Politics of Contemporary Transitional Justice, 38 CORNELL INT'L L.J. 837, 855 (2005). 
more successful at achieving its overarching aim through an expansion of the policy of proactive complementarity. In particular, I will suggest that the ICC may exert a type of "moral suasion" that can aid countries in maintaining the momentum and quality of transitional justice projects. ${ }^{96}$ In general, the field of transitional justice concerns itself with the mechanisms adopted by governments seeking to address past episodes of political violence, repression, armed conflict, and other situations that give rise to systematic violation of human rights and humanitarian law. ${ }^{97}$ Recent ICC scholarship has begun to discuss the appropriate role of the ICC with relation to states undergoing a transitional justice process where they opt to establish truth commissions, open criminal prosecutions, conduct trials, facilitate alternative dispute mechanisms, and promote institutional reforms. ${ }^{98}$ These ICC scholars often look at how these local justice initiatives potentially raise issues with the ICC's jurisdiction..$^{99}$

Certainly, this new direction in the literature reflects the simple fact that most situations that will trigger the ICC's jurisdiction will also trigger the initiation of transitional justice processes because both are concerned with conflict and post-

96. I borrow the concept of "moral suasion" from Christine $H$. Chung as a sort of "soft" power in the ongoing process of enforcing international law. Christine H. Chung, The Punishment and Prevention of Genocide: The International Criminal Court as a Benchmark of Progress and Need, 40 CASE W. RES. J. INT'L L. 227, 241 (2007).

97. TEITEL, supra note 18; The Dilemmas of Transitional Justice in 1 TRANSITIONAL JUSTICE: HOW EMERGING DEMOCRACIES RECKON WITH FORMER REGIMES xix (Neil J. Kritz ed. 1995).

98. See generally Jennifer S. Easterday, Deciding the Fate of Complementarity: A Colombian Case Study, 26 ARIZ. J. INT'L \& COMP. L. 49 (2009) (examining influence of ICC with regard to Columbia's Ley de Paz y Justicia); Greenawalt, supra note 18, at 128 (discussing the ICC's deference to alternative peace processes in Uganda); Linda M. Keller, Achieving Peace with Justice: The International Criminal Court and Ugandan Alternative Justice Mechanisms, 23 CONN. J. INT'L L. 209, (2008) (analyzing the ICC's tensions with the Lord's Resistance Army (LRA) in Uganda's peace negotiations); Christopher D. Totten, The International Criminal Court and Truth Commissions: A Framework for Cross-Interaction in the Sudan and Beyond, 7 NW. U.J. INT'L HUM. RTS. 1 (2009) (using the case of Sierra Leone's international tribunal and truth commission to propose an approach for the ICC to similar situations).

99. See Easterday, supra note 98, at 50 (examining influence of ICC with regard to Columbia's Ley de Paz y Justicia); Brian Concannon examines proactive complementarity with regard to Haiti's transition that included prosecutions for crimes from 1991 to 1994 , and thus technically does not trigger the ICC's jurisdiction. He does not, however, address that issue but rather seems to propose Haiti as a hypothetical case of what it would look like for the ICC to get involved in situations that could become admissible. Brian Concannon, Beyond Complementarity: The International Criminal Court and National Prosecutions, A View from Haiti, 32 COLUM. HUM. RTS. L. REV. 201 (2000). 
conflict settings. ${ }^{100}$ This intersection of interest is likely to become more common with increasing resort to transitional justice mechanisms that have become a sort of staple ingredient in postconflict reconstruction. ${ }^{101}$ Yet again, this scholarly literature still focuses on countries that technically fall within the temporal restrictions of the Rome Statute because the authors examine country situations where the transitional justice process concerns itself with international crimes occurring after 2002. Once again, this arbitrary temporal demarcation means some post-conflict reconstruction projects will fall under the ICC's radar even if they directly relate to the Court's overarching mission of ending impunity and preventing future atrocities. Alternatively, if the ICC interpreted the principle of proactive complementarity more liberally and played a more active role even if not requiring excessive involvement and interference-it could serve as a critical presence that can help lend support and assure the sustainability of these often fragile undertakings.

\section{A. The Transitional Justice Project of Peru}

I will use the case of Peru to demonstrate what an expanded proactive complementarity policy might entail-and alternatively, where its absence can be most felt. Peru offers an interesting case study to explore some current limits to the influence of the ICC in advancing its overarching mission in a transitional justice project dealing with international crimes occurring from 1980 until 2000, and thus before the Rome Statute entered into force.

Indeed, Peru began its political transition in 2001 after a decade of repressive rule by Alberto Fujimori who, after being elected in 1990, went on to orchestrate a self-coup in 1992, closed Peru's parliament, removed its high court justices, and rewrote the national constitution. ${ }^{102}$ Yet, Fujimori enjoyed widespread support given the general population's incredible fear and desperation to defeat the terrorism that had paralyzed the country since 1980 when the Maoist group Sendero Luminoso declared a popular war against the state. The draconian anti-terrorist laws, death squads, and amnesty laws employed by Fujimori, however, led to absolute

100. See Dragana Radosavljevic, An Overview of the ICC Complementarity Regime, 1 USAK Y.B. INT'L POL. \& L. 125, 126 (2008) (noting that most cases ICC will deal with will be conflict or post conflict).

101. A watershed moment in the "mainstreaming" of transitional justice occurred with the publication of The Secretary-General, Report of the Secretary-General on the Rule of Law and Transitional Justice in Conflict and Post-conflict Societies, U.N. Doc. S/2004/616 (Aug. 23, 2004).

102. Lisa J. Laplante, The Rule of Law in Transitional Justice: The Fujimori Trial in Peru, in 3 THE RULE OF LAW IN COMPARATIVE PERSPECTIVE, IUS Gentium: Comparative Perspectives on LaW and Justice, (Mortimer Sellers \& Tadeusz Tomaszewski eds., forthcoming 2010). 
impunity for serious human rights violations. ${ }^{103}$ For example, it eventually came to light that the government of Fujimori had created a death squad named "Colina" to target opponents and suspected rebels. Among its long list of crimes, Colina carried out two notorious massacres: Barrios Altos in 1991 (a raid and killing of fifteen people at a neighborhood cook-out fundraiser) and Cantuta in 1992 (the abduction and extrajudicial assassination of nine university students and a professor). ${ }^{104}$ Ultimately, the steady erosion of the rule of law allowed Fujimori to be re-elected two more times despite the serious concern of the international community and suggested that he enjoyed a solid grip on power. Given this situation, Peruvians were caught by surprise when Fujimori suddenly fled the country in November 2000 following widespread corruption scandals. ${ }^{105}$

Peru's transitional government sought to re-establish itself in the international community as a law abiding country and understood this task required setting up domestic mechanisms to address the break-down of the rule of law and impunity. To facilitate this process, the interim president, Valentín Paniagua, established a special working group to begin to study and propose how to redress the harm caused by both the years of internal armed conflict as well as the decade of repressive rule under the regime of Alberto Fujimori. ${ }^{106}$ In no uncertain terms, the judicial working group composed of many former human rights activists understood the value of engaging with international legal systems that would support its endeavors despite strong power holdovers from the previous regime. Part of its strategy to align itself with the international community's legal norms in order to regain international legitimacy included joining the Rome system of justice. ${ }^{107}$

\section{B. International-National Cooperation Laws}

Peru ratified the Rome Statute in 2001 with the intention of drafting legislation to harmonize its domestic legislation with the Rome Statute. ${ }^{108}$ Notably, Peru became one of the first countries to

103. Lisa J. Laplante, Outlawing Amnesty: The Return of Criminal Justice in Transitional Justice Schemes, 49 VA. J. INT'L L. 915, 953 (2009).

104. Id. at 915.

105. Ernesto García Calderón, High Anxiety in the Andes: Peru's Decade of Living Dangerously, 12 J. DEMOCRACY 46, 46 (2001).

106. Lisa J. Laplante, Entwined Paths to Justice: The Inter-American Human Rights System and the Peruvian Truth Commission in PathS TO InTERnational Justice: Social and Cultural Perspectives 222 (Marie Dembour \& Tobias Kelly eds., 2007).

107. Id.

108. Peru ratified the Rome Statute on November 10, 2001. Coalition for the International Criminal Court, Peru, http://www.coalitionfortheicc.org/?mod= country\&iduct=137 (last visited Apr. 10, 2010). 
promulgate the necessary internal laws to ensure international cooperation with the Court, as contained in Article 86 (General obligation to cooperate). ${ }^{109}$ Specifically, the Peruvian law ${ }^{110}$ responds to the general provision of Article 88 (availability of procedures under national law) ${ }^{111}$ in order to assure that it can surrender persons to the Court ${ }^{112}$ and other forms of cooperation outlined in the Rome Statute. ${ }^{113}$ Significantly, Peru is now legally bound by both treaty law and domestic law to cooperate with the ICC. Indeed, Burke-White recognizes that this range of state obligations "taken collectively, may provide an additional legal foundation for a policy of proactive complementarity." 114 In other words, if the object and purpose of the Rome Statute is to create a cohesive international-national collaborative system that creates new treaty obligations on States Parties to align their domestic systems, then shouldn't the ICC be more involved in overseeing this harmonization process even if in a mere oversight fashion? On the contrary, a lack of any involvement seems to naively expect that States Parties are automatically taking such positive steps, only to be confronted with inadequacies in the off-chance that they come to light through a situation investigated by the ICC that requires state cooperation.

Arguably, this same viewpoint could apply to the ongoing effort to align domestic penal codes with the Rome Statute although not explicitly required by the Rome Statute. Indeed, despite the explicit requirement that States Parties "amend their national law to ensure that procedures will exist to cooperate with the ICC, there is no analogous provision requiring national laws to be amended to substantively incorporate the crimes defined in the Rome Statute."115 Regardless, Peru also initiated a process to harmonize its substantive penal codes with the Rome Statute by drafting bills to incorporate the substantive crimes of the Rome Statute into domestic law, most notably the crimes enumerated in

109. "States Parties shall, in accordance with the provisions of this Statute, cooperate fully with the Court in its investigation and prosecution of crimes within the jurisdiction of the Court." Rome Statute, supra note 2, art. 86.

110. Código PRocesal Penal Libro Séptimo (Peru). The section on Cooperation came into force on February 1, 2006. Id.

111. "States Parties shall ensure that there are procedures available under their national law for all of the forms of cooperation which are specified under this Part." Rome Statute, supra note 2, art. 88.

112. Id. art. 89.

113. See, e.g., Id. art. 93. Article 93 (other forms of cooperation), provides that the ICC may request that a state assists with investigations or prosecutions through a variety of actions, ranging from locating persons and items, conducting searches and seizures, taking depositions under oath, and protecting victims, witnesses and evidence, among other critical activities essential for a successful prosecution.

114. Burke-White, supra note 4 , at 82 .

115. Perrin, supra note 30 , at 310 . 
Article 5 (crimes within the jurisdiction of the Court) such as genocide, crimes against humanity, and war crimes.

Specifically, in October 2002, the Peruvian legislature created the Special Revision Commission of the Penal Code (Spanish acronym, CERCP) to revise the penal code to reflect Peru's commitment to the Rome Statute. ${ }^{116}$ As a result, CERCP created a legislative proposal entitled "Adecuación de la Legislación Penal al Estatuto de Roma de la Corte Penal Internacional" (alignment of penal laws with the Rome Statute of the International Criminal Court) on December 10, 2003.117 The proposal did not reach the national congress, however, until 2006 when it was presented to the Congressional Commission of Justice and Human Rights (Comisión de Justicia y Derechos Humanos del Congreso).118 The Commission converted the proposal into a bill ${ }^{119}$ that slowly moved forward during the democratic government of Alejandro Toledo (2001-2005), with only a few interruptions due to congressional recesses. The initiative began to face formidable challenges with the change of administration.

Most notably, political change occurred when Alan Garcia entered office in 2006 for a second time despite serious allegations that he committed gross human rights violations during his first term as president (1984-1990). ${ }^{120}$ Under this new leadership, congressional members belonging to Garcia's political party Alianza Popular Revolucionaria Americana (APRA) along with that of Fujimori (commonly referred to as the 'fujimoristas'), watered down the original bill designed to fully incorporate the substantive crimes of the Rome Statute, and eventually kept it off the political agenda. Interestingly, part of the reason for obstructing the bill related to misunderstandings regarding issues of retroactivity and the concept of complementarity and when the ICC could get involved in a case regarding members of their own political party. ${ }^{121}$ Potential issues that might arise in the future due to this failure to fully harmonize Peruvian domestic laws with

116. The original title in Spanish is Comisión Especial Revisora del Código Penal, and was established under Ley No. 27837 (2002). Coalition for the International Criminal Court, Updates on Peru, http://www.coalition fortheicc.org/? $\bmod =$ newsdetail\&news=265 (last visited Apr. 10, 2010); Miguel HUERTA BARRON ET. AL., COMISEDH, COMENTARIOS SOBRE ASPECTOS RELEVANTES PARA LA PROPUESTA NORMATIVA 9 (2008).

117. HUERTA, supra note 116 , at 10.

118. Id.

119. Proyecto del Ley 14659/2005-CR, (May 3, 2006). HUERTA, supra note 116 , at 10 .

120. HUMAN Rights WATCh, ALAN GaRcia's SECOND CHANCE: Human RIGHTS ACCOUNTABILITY IN PERU 2 (2006), available at www.hrw.org/pub/ memos/peru0806.pdf.

121. Telephone interview with a former Peruvian legal advisor working in the committee promoting the bill (April 8, 2010). 
the Rome Statute became apparent during the criminal trial of Fujimori.

\section{The Historic Human Rights Trial of Alberto Fujimori}

The criminal trial of Alberto Fujimori took place from September 2007 until April 2009, but only after years of Peru seeking his extradition first from Japan and then from Chile. Indeed, when Fujimori fled in November 2000, he found a safe haven in Japan given his dual citizenship. ${ }^{122}$ In March 2003, Interpol issued an arrest warrant for Fujimori for his alleged responsibility in the extrajudicial assassinations of Barrios Altos in 1991 and Cantuta in 1992, emblematic massacres carried out by the death squad Colina, which Fujimori formed to carry out his illicit campaign against terrorism. On July 31, 2003, the Peruvian government formally solicited Fujimori's extradition from Japan based on corruption and human rights charges. But Japan refused extradition on the grounds that Fujimori was a Japanese citizen, his parents having been born there.

Meanwhile, Fujimori's radio emissions from Japan made clear that he was determined to return to Presidential office in Peru one day, indicating a striking indifference to the threat of being held criminally liable. Indeed, he surprised the world when he arrived in Chile on November 6, 2005, in a private jet with a stop-over in Mexico that ended in Chile. The day after Fujimori's arrival, the Chilean Supreme Court ordered his detention and several months later, the Peruvian government presented a new extradition petition. The petition included thirteen criminal charges for corruption and human rights violations, including the assassination of Barrios Altos and Cantuta, as well as an abduction and torture of a businessman and journalist in the basement of a military intelligence service building. Eventually, the Chilean Supreme Court ruled on September 10, 2007, in favor of Peru's extradition request. On September 22, 2007, the fallen leader was escorted back to Peru to be immediately incarcerated in a specially built prison on the eastern periphery of Lima. ${ }^{123}$

On December 10, 2007, proceedings began against Fujimori for the human rights violations associated with the cases of Barrios Altos and Cantuta, among other charges. After some 160 trial sessions, eighty witnesses, and hours of court hearings, the Permanent Criminal Chamber of the Peruvian Supreme Court convicted Fujimori on April 7, 2009, sentencing him to twenty-five years in prison for human rights abuses committed as a result of

122. García Calderón, supra note 105 , at 55 .

123. Jo-Marie Burt, Guilty as Charged: The Trial of Former Peruvian President Alberto Fujimori for Human Rights Violations, 3 INT'L J. TRANSITIONAL JUST. 384, 396 (2009). 
his assault on the rule of law. ${ }^{124}$

While in the 1990s few Peruvians could have realistically expected this outcome, the developments in international criminal and human rights law made Fujimori's criminal trial a more natural step toward ending impunity. ${ }^{125}$ In many ways, the Fujimori trial epitomizes the vision of effective domestic proceedings embodied in principle of complementarity that serves as a foundation for the Rome system of justice.

For these reasons, international and national observers followed the trial to assure that it not only respected the due process rights of the defendant, but also the norms of international criminal law. Yet notably, the ICC had no presence in this process, neither through physical monitoring, nor other diplomatic communications to express interest or concern about the trial, despite the trial's direct implication for the development of international criminal law as well as contributing to the ICC's mission. ${ }^{126}$ One of the most direct results of this absence is that a review of newspaper archives during Fujimori's trial until the appeal of his conviction reveals no discussion of the ICC with reference to the Fujimori trial. It is as if the international court did not even exist. My conversations with national and international trial observers reveal that the most obvious explanation for the striking disconnect between the national and international criminal regimes relates to the strict jurisdictional rules of Article 17, and the temporal limit to its scope. These observers did not even seem to question the absence of the ICC, consistently explaining the absence of the ICC in terms of its "mandate," clearly adopting the narrow view of the ICC's mission to relate only to admissibility and jurisdiction. In other words, the Fujimori trial would not interest the ICC because it would never fall within its jurisdiction.

It could be argued that this disconnect between the international forum and the national forum may not matter given that Fujimori was successfully convicted and sentenced to twentyfive years, a decision that was eventually affirmed upon appeal in 2009. Yet if recalling the broader interpretation of the ICC's mandate to help the international community combat impunity, several reasons could suggest why the Court might have paid more attention to the Fujimori case. Indeed, the Fujimori trial, despite falling outside of the ICC's purview, had several far-reaching

124. Id. at 384 .

125. Steven Freeland, The Internationalization of Justice-A Case for the Universal Application of International Criminal Law Norms, 4 N.Z. Y.B. INT'L L. 45, 46-7 (2007) (discussing the universalization of human rights norms).

126. E-mail from Antônia Pereira de Sousa, Associate Cooperation Office, Office of the Prosecutor International Criminal Court, to author (Apr. 1, 2010) (on file with author). 
implications for the future of the international-national collaboration model supposedly promoted by the ICC, as I will discuss next.

\section{Ordinary Offenses: Testing the "Ability" of National Courts to Prosecute International Crimes}

Despite the notable absence of the ICC during the various stages of bringing Fujimori to justice, the Court's subject matterinternational crimes-was front and center in the trial. In fact, for this reason, the non-governmental Coalition for the International Criminal Court (CICC) observed the trial in order to see how the court addressed issues of international criminal law. ${ }^{127}$ Peru's special criminal chamber, established to conduct the trial, grappled with how to apply the charge of crimes against humanity, although facing questions of legality due to a lack of full codification of this crime in domestic law. While Fujimori faced charges that arose out of "ordinary offences" of murder and kidnapping, the Peruvian court sought to convey the seriousness of these crimes as part of a systematic plan that, in essence, arose to the level of crimes against humanity.

The final judgment consists of 700 pages, but crimes against humanity are not discussed until much later in the opinion and the justices dedicate fewer pages to its analysis than other relevant issues in the case. In the end, the court uses the concept of crimes against humanity to convey the seriousness of Fujimori's alleged transgressions even if not charged with the international crime, which it refers to as "offending general principles of international law and of great concern to the international community."128 The Peruvian Court's opinion provides a brief history of the Nuremberg trial as the origin of crimes against humanity, also making references to the codification of the crime in Article 5 of the Statute of the International Criminal Tribunal of the Former Yugoslavia (ICTY), Article 3 of the Statute of the International Criminal Tribunal of Rwanda (ICTR), and finally Article 7 of the Rome Statute. ${ }^{129}$ In footnote 1023, the Court addresses the duty of states to prosecute international crimes because the protection of individuals does not "end in state and national jurisdictions, but rather complements and reinforces international norms." 130

127. Correspondence from CICC representative to author (Mar. 15, 2010) (on file with author).

128. Corte Suprema de Justicia de la Republica, Sala Penal Especial, Parte Tercera, Fundamentos Juridicos Penales, Capitulo 1: Delitos Cometidos, Exp. N A.V. 19.2001, If 710 (Peru) (author's translation) [hereinafter Corte Suprema].

129. Id.

130. Id. If 711. The court also refers to an opinion of the Tribunal 
The Court also refers to an amicus curiae submitted by Washington University Law School, which argues that all nations have the duty to prosecute perpetrators of international crimes as well as observe jurisprudence of international tribunals with respect to "conduct" that arises to the level of international crime. ${ }^{131}$ Although the amicus argues that Peru ought to be able to apply these norms directly in its national jurisdiction, the Peruvian Special Court encounters difficulty getting around questions of legality due to the lack of codification at the time that Barrios Altos and Cantuta occurred.132 Thus, the Court opts to acknowledge that while Fujimori is being convicted for homicide and kidnapping, these offenses can be "characterized as crimes against humanity." 133 It even dedicates several more paragraphs to discussing how assassination falls within the elements of crimes against humanity as recognized in Article 7 of the Rome Statute. Thus, while no public discussion of the ICC occurred during the trial by the press or general public, the topic did enter the chambers via the amicus of interested universities, albeit arguably in only a minimal fashion.

Yet, the Peruvian Court's use of "ordinary offences" to convict Fujimori for what otherwise constitutes an international crime, potentially puts into question Peru's "ability" to effectively prosecute international crimes, one of the admissibility standards used by the ICC to determine whether it has jurisdiction under Article 17. Indeed, the use of "ordinary crimes" to define international crimes within national jurisdictions "may well be the hidden weakness in the complementarity regime as an effective limit to supranational power."134 The lack of clarity means that eventually the ICC will need to "cope with the gap between national proceedings on the ordinary crimes basis and proceedings utilizing the Rome Statute language."135

While still not tested through an actual case before the ICC, academics debate whether the use of ordinary crimes could amount to a finding of "inability" within the meaning of Article 17(3) of the Rome Statute because it fails to sufficiently implement the elements of international crimes in accordance with the Rome Statute. ${ }^{136}$ The issue relates to whether complementarity

Constitutional that recognizes that international law falls within the same hierarchy as national law. Tribunal Constitutional 2209-2002-AA/TC (Peru).

131. Informe de Derecho: La Dimension Internacional del proceso penal contra el ex president Alberto Fujimori por los crimenes de Barrios Altos y la Cantuta, 20, 25, 27 (June 2008).

132. PERUVIAN CONSTITUTION art. 2; PENAL CODE art. 24.d.

133. Corte Suprema, supra note 128 , at 9711.

134. Newton, supra note 17 , at 70.

135. Sheng, supra note 49 , at 451.

136. Jenia Iontcheva Turner, Nationalizing International Criminal Law, 41

STAN. J. INT'L L. 1, 50 (2005) (taking the position that ordinary offence 
embodied in Article 17(2) "presupposes that states must have adequate legislation (both in terms of substantive and procedural law) enabling them to genuinely prosecute war criminals according to 'proper' categories of crimes." 137 Indeed, even if the Rome Statute does not explicitly require harmonization, scholars have suggested that the complementarity principle in Article 17 in fact places a de facto obligation on states to align their domestic substantive law to include the range of offenses under the Rome Statute, or otherwise, run the risk that the OTP might deem the state "unable" to prosecute those crimes. ${ }^{138}$ Put simply, "[t] he mere existence of the legislative framework is fundamental because there can be no utilisation of that framework in circumstances where it does not exist."139 Thus, for example, if a national court convicts someone of ordinary crimes for facts that amount to genocide, then the ICC could retain jurisdiction. ${ }^{140}$ Others opine that application of "ordinary offences" do not give rise to "automatic admissibility" to the ICC, pointing to the drafting history of the Rome Statute and the choice of the word "conduct" and not "crimes" to enfold the possibility of acts that could be prosecuted for both ordinary and international crimes. ${ }^{141}$ Yet despite these contentions, it remains "an open question" whether ordinary offences suffice to satisfy Article 17's ability criteria. ${ }^{142}$

Scholars cannot find clear guidance from the jurisprudence of the ICTY or ICTR due to the fact that they explicitly refer to the issue of "ordinary crimes." In fact, the ICTY and ICTR establish an

application to international crimes would trigger ICC jurisdiction); Flavia Lattanzi, The International Criminal Court and National Jurisdictions in THE ROME STATUTE OF THE INTERNATIONAL COURT: A CHALLENGE TO IMPUNITY 181 (Mauro Politi \& Giuseppe Nesi eds., 2001) ("The lack of implementation in domestic legal orders of applicable international standards . . could lead to the Court's decision of the admissibility of a case, as a consequence of the 'incapability' of the national jurisdictions to provide justice in the case." (citation omitted)).

137. Benzing, supra note 39 , at 615 .

138. Newton, supra note 17, at 71; see also Douglas Cassel, The ICC's New Legal Landscape: The Need to Expand U.S. Domestic Jurisdiction to Prosecute Genocide, War Crimes, and Crimes against Humanity, 23 FORDHAM INT'L L.J. 378 (1999) (arguing that U.S. should harmonize its substantive penal codes to avoid future interference of ICC); Katherine L. Doherty \& Timothy L.H. McCormack, 'Complementarity' as a Catalyst for Comprehensive Domestic Penal Legislation, 5 U.C. DAVIS J. INT'L L. \& POL'Y 147 (1999) (analyzing how Australia's national penal code fell short of Rome Statute, suggesting it might become susceptible to ICC's concurrent jurisdiction).

139. McCormack, supra note 1 , at 46.

140. Perrin, supra note 30 , at 310.

141. Kleffner, supra note 7, at 95-96; Immi Tallgren, Article 20: Ne bis in idem, in COMMENTARY ON THE ROME STATUTE: OBSERVERS' NOTES, ARTICLE BY ARTICLE 419, 430 (Otto Triffterer ed., 1999).

142. Burke-White, Complementarity in Practice, supra note 73, at 582. 
exception to the general principle of non bis in idem to allow international jurisdiction over cases where a person was convicted of ordinary crimes that in fact constitute serious international crimes. ${ }^{143}$ Further, the ICTY wrote in dicta that an international criminal tribunal "must be endowed with primacy over national courts" because human nature will create a "perennial danger of international crimes being characterized as ordinary crimes." 144 Here, Professor Schabas notes that even if

[i]t will be argued that the trial for an underlying offence tends to trivialize the crime and contribute to revisionism or negationism. Many who violate human rights may be willing to accept the fact that they have committed murder or assault, but will refuse to admit the more grievous crimes of genocide or crimes against humanity. Yet murder is a very serious crime in all justice systems and is generally sanctioned by the most severe penalties. ${ }^{145}$

More than mere terminology, the difference relates to capturing the gravity of the crime as well as assuring the corresponding sanction that adequately reflects the seriousness of the offence. For example, there may be cases where the penalty for murder will not adequately reflect the seriousness of an international crime. ${ }^{146}$ Fujimori faces twenty-five years for his ordinary offenses despite the fact that his crimes included two significant massacres of over twenty-five people and were chosen as part of the prosecution strategy to reflect a general policy and pattern of government abuse. While the gravity of crimes against humanity largely occurs due to the requirement that it be part of a widespread or systematic attack, murder in its ordinary criminal sense applies to one isolated killing. ${ }^{147}$ Thus, sentencing presents a major challenge in this unresolved tension between national and international jurisdictions. ${ }^{148}$

The question remains whether the precedent could ever be

143. Statute of the International Criminal Tribunal for the Former Yugoslavia art. 10 (2)(a), Res. 827, U.N. Doc. S/Res/827 (May 25, 1993); Statute for the International Criminal Tribunal for Rwanda art. 9(2)(a), S.C. Res 955, U.N. Doc. S/955 (Nov. 8, 1994).

144. Prosecutor v. Tadic, Case No. IT-94-AR72, Appeals Chamber Decision on the Defense Motion for Interlocutory Appeal on Jurisdiction, If 58 (Oct. 2, 1995), http://www.icty.org/x/cases/tadic/acdec/en/51002.htm.

145. WILLIAM SCHABAS, AN INTRODUCTION TO THE INTERNATIONAL CRIMINAL COURT 70 (2001).

146. Burke-White, Complementarity in Practice, supra note 73, at 582.

147. See, e.g., Rome Statute, supra note 2, art. 7 (defining "crimes against humanity."). This view is adopted in El Zeidy, supra note 42, at 933.

148. See, e.g., Steven Glickman, Victims'Justice: Legitimizing the Sentencing Regime of the International Criminal Court, 43 CoLUM. J. TRANSNAT'L L. 229, 259 (2004) (noting that ICC statute "fails to provide a framework to achieve much-needed consistency" in sentencing). See generally Allison Marston Danner, Constructing a Hierarchy of Crimes in International Criminal Law Sentencing, 87 VA. L. REV. 415 (2001). 
used against Peru with regard to its ability to adequately prosecute and punish international crimes. Without clarity on the issue of "ordinary offences," Peru may have established a precedent that could be used against it in future instances requiring it to satisfy the "ability" requirement. For example, as a State Party to the Rome Statute and pursuant to both its national and international legal obligations, Peru now stands poised at any moment to need to cooperate with the Court regarding cases falling within the ICC's Article 17 jurisdiction. Arguably, the Fujimori trial served as an important moment for Peru to demonstrate that it is fulfilling its general obligation under the Rome Statute, regardless of whether the ICC could ever obtain jurisdiction over the specific case of Fujimori. Its performance might prove relevant for evaluating future cases which do fall within the ICC's temporal jurisdiction.

Certainly, while the Fujimori trial was underway, the incumbent President Alan Garcia engaged in activity that raised questions as to whether he should be held to account for systematic human rights violations. Indeed, despite the significant advances in Peru's transitional justice project after the downfall of Fujimori, there has been a backslide due to the "heavy handed" rule of Alan Garcia. In July 2007, Garcia began attacking civilians protesting socio-economic grievances especially related to the clashes between indigenous landholders and big extractive companies. Garcia labeled the protesters as "terrorists," tapping into the continued divisions in Peru, and arguably contributing to the escalation of confrontation between civilians and state armed forces. After one such fatal incident, Garcia passed a draconian law that virtually shielded the armed forces from having to respect rights during protests. ${ }^{149}$

Within this already tense setting, another violent encounter arose in June 2009 when indigenous communities in Bagua were protesting legislative decrees that sought to favor foreign investments at the risk of jeopardizing indigenous rights to land and cultural identity. ${ }^{150}$ An estimated nine civilians and twentyfour police officers died, leading some segments of Peru to accuse the government of planned genocide. ${ }^{151}$ Significantly, a survey of newspaper archives reveals that during this time, readers

149. Lisa J. Laplante, Transitional Justice and Peace Building: Diagnosing and Addressing the Socioeconomic Roots of Violence Through a Human Rights Framework, 2 INT'L J. TRANSITIONAL TRANSNAT'L JUST. 331, 332 (2008).

150. Simon Romero, Protestors Gird for Long Fight Over Opening Peru's Amazon, N.Y. TIMES, June 12, 2009, at A6.

151. Mirko Lauer, Bagua: no se puede manejar el tema con vaguedades, LA REPÚBLICA PERÚ, June 9, 2009, available at http://www.larepublica.pe/observador/09/06/2009/bagua-no-se-puede-manejarel-tema-con- vaguedades. 
frequently called for the intervention of the ICC and one organized group even submitted a complaint to that body. ${ }^{152}$ Although media reporting on the ICC in Peru is relatively modest, it still reflects a growing awareness of the existence of an international mechanism for accountability. Tim McCormack views media reporting in accountability measures as significant for making "international law from the esoteric to the mainstream."153

Another way that Peru could find itself entangled in a dispute potentially triggering the interest of the ICC relates to its granting refuge to Jorge Torres Obleas despite Bolivia's protests. ${ }^{154}$ Specifically, Peru granted asylum to Obleas, the former economic development minister during the second government of President Gonzalo Sanchez de Lozada, who governed Bolivia from 1993-1997 and 2002-2003. The Bolivian government pressed charges against Obleas and two other former ministers on charges of aiding a military crackdown that led to more than sixty deaths in 2003, an episode known as the "Black October" killings. ${ }^{155}$ In this situation, Peru could potentially face the situation where, if a prima facie case against Olbeas can be made implicating him in international crimes, then the obligation of aut dedere aut judicare could be triggered obligating Peru to either prosecute or extradite him. ${ }^{156}$ This situation would call into question Peru's "ability" to prosecute international crimes and potentially require it to cooperate with the Court or relinquish jurisdiction in the name of cooperating with the ICC. 157

152. Larepublica.pe, Acuerdan huelga indefinida en Amazonia, http://www. larepublica.pe/bagua-masacre/08/06/2009/acuerdan-huelga-indefinida-en amazonia?page $=1$ (the IV Cumbre Amazonica denounced president Alan Garcia in front of national and international tribunals including the ICC) (last visited Aug. 2, 2010); Larepublica.pe, MTC si otorgo certificado de Homologacion de Equipos a Radio La Voz, http://www.larepublica.pe/ regionales/13/06/2009/mtc-si-otorgo-certificado-de-homologacion-de-equiposradio-la-voz (last visited Aug. 2, 2010); Larepublica.pe, Reader Comments to Article, Fiscalia confirma que nativos de Bagua no portaban armas de fuego, http://www.larepublica.pe/regionales/22/07/2009/fiscalia-confirma-que-nativosde-bagua-no-portaban-armas-de-fuego (last visited Aug. 2, 2010) Larepublica.pe, Evo Morales no pedira perdon por haber hablando de genocidio en Peru, http://www.larepublica.pe/bagua-masacre/21/06/2009/evomorales-no-pedira-perdon-por-haber-hablado-de-genocidio-en-peru?page=1

(last visited Aug. 2, 2010).

153. McCormack, supra note 1 , at 35 .

154. Larepublica.pe, Evo Morales no descarta romper relaciones diplomaticas con Peru, http://www.larepublica.pe/archive/all/larepublica/20090514/2/15/ todos/15 (last visited Aug. 2, 2010).

155. Peru Grants Asylum to Bolivian Ex-Minister; 2 Cases Pending, LatiN AM. HERALD TRIB., available at http://laht.com/article.asp?CategoryId=14095 \&ArticleId $=334287$.

156. Gennady M. Danilenko, The Statute of the International Criminal Court and Third States, 21 MICH. J. INT'L L. 445, 478 (2000).

157. See Mark S. Ellis, The International Criminal Court and its 
Significantly, these new situations could now trigger the ICC's jurisdiction given that they occurred after 2002. The fact that they also took place concurrent with Fujimori's trial might suggest that the ICC would have had a more justified reason for making its interest in the Fujimori trial known, to allow Peru to showcase the trial as Peru's proof of its willingness and ability to try these types of crimes.

While admittedly academic speculation, it is possible to imagine that had the ICC perhaps paid attention during the Fujimori trial, Peru would have also been put on notice of the inadequacy of its domestic legislation. The Court could have sent an important message to Peru had it simply indicated that it was abreast of the Fujimori trial while also raising awareness of the ways in which it might provide an example (or not) on how states might prove their "ability" to conduct domestic prosecutions. Yet in light of the "ordinary offences" issue, this attention might have opened discussion among the Peruvian elite most resistant to the substantive harmonization with the Rome Statute. Political opponents to the bill could have been educated that, in fact, this harmonization would be an important protection against ICC interference. Even if this "avoidance strategy" may appear an "ignoble" motivation to harmonize domestic legislation, the end result favors the mission of the ICC. ${ }^{158}$ While arguably the incentive for this harmonization process comes from a defensive posture of avoiding ICC interference, it could also be viewed more positively as contributing to an increase of national prosecutions and thus the success of the ICC. ${ }^{159}$

\section{EXPANDING THE INFLUENCE OF THE ICC}

The discussion on determining Peru's ability to prosecute international crimes raises the question of whether the ICC should be more proactive in assisting states to reach this threshold before it ever becomes a contentious issue related to jurisdiction. Certainly, some assume that "States Parties have been tacitly encouraged to improve their domestic implementation of international criminal law. By its mere existence the ICC has played a role of standard setter." 160 Yet based on the experience in Peru it could be argued that the ICC may need to do more than "merely exist" in order to influence the development of international criminal law. Moreover, the appropriate role of the ICC becomes more pressing when adopting the view that the Rome

Implications for Domestic Law and National Capacity Building, 15 FLA. J. INT'L L. 215, 231-32 (2003) (discussing issues presented with regard to extraditable offenders and requirement to cooperate with ICC).

158. McCormack, supra note 1 , at 45 .

159. Doherty \& McCormack, supra note 138 , at 152.

160. Perrin, supra note 30 , at 316 . 
Statute reflects the international community's desire "to maintain some semblance of 'uniformity' in the way the world combats genocide, crimes against humanity and war crimes." 161 Moreover, the lack of an explicit requirement in the Rome Statute to incorporate substantive law regarding serious international crimes does not absolve states of the obligation to do so since the Statute codifies existing treaty and customary law that often already bind States Parties of the ICC. ${ }^{162}$

Thus, "the central question is whether it will promote national proceedings in an unqualified manner to the extent that 'nearly anything goes' or whether it will stress a number of principles and rules purporting to inform and constrain such proceedings."163 Arguably, the case study of Peru suggests that, despite the attraction of a laissez-faire approach to the evolving Rome system of justice, it may in fact be necessary for the ICC to take a more deliberate and positive approach to national proceedings if it hopes to more effectively and efficiently realize its mission. A broader reading of the doctrine of complementarity assumes a more purposeful harmonization of national norms and practices to those established by the ICC to assure the vitality and longevity of the burgeoning system of international criminal lawthe Rome system of justice.

But what entity oversees or even encourages this process? Unlike international human rights systems, which assume as part of their overarching missions the harmonization of national settings with human rights norms, ${ }^{164}$ the Rome Statute does not seem to contemplate any type of analogous entity to assure this process in the international criminal law system currently being

161. Sheng, supra note 49 , at 426.

162. Leila N. Sadat, Custom, Codification and Some Thoughts About the Relationship Between the Two: Article 10 of the ICC Statute, 49 DEPAUL L. REV. 909, 918 (2000).

163. Almqvist, supra note 22 , at 350 .

164. For example, the American Convention on Human Rights art. 2, Nov. 22, 1969, 1144 U.N.T.S. 123 , which requires:

Where the exercise of any of the rights or freedoms referred to in Article 1 is not already ensured by legislative or other provisions, the States Parties undertake to adopt, in accordance with their constitutional processes and the provisions of this Convention, such legislative or other measures as may be necessary to give effect to those rights or freedoms. Id.

Similarly, the International Covenant on Civil and Political Rights art. 2, Dec. 16, 1966, 999 U.N.T.S. 171, indicates:

Where not already provided for by existing legislative or other measures, each State Party to the present Covenant undertakes to take the necessary steps, in accordance with its constitutional processes and with the provisions of the present Covenant, to adopt such laws or other measures as may be necessary to give effect to the rights recognized in the present Covenant.

Id. 
developed. ${ }^{165}$ Should we assume that the negotiators of the Rome Statute overlooked the need for a similar type of entity to assure the coherent and progressive harmonization of the system? Or on the contrary, could we imply this function when applying a broader interpretation of the Rome Statute purpose within a Rome system of justice?

Critics of this idea may claim that such a role would risk making the ICC "like an NGO," that is, a non-profit, nongovernmental organization, raising some fears of the politicization of the Court which would undermine its legitimacy. ${ }^{166}$ But this outcome need not be the case. For example, entities like the United Nations Human Rights Committee (UNHRC), which oversees the implementation and enforcement of the International Covenant on Civil and Political Rights, assumes the role of not only receiving complaints as part of a litigation process, but also facilitates and encourages the ongoing alignment of national systems so as to assure respect for human rights, and by necessity, the prevention of atrocities. Few criticize the Committee as being like NGOs. In fact, despite its arguably political work, the Committee manages to garner great respect for its necessary role and is rarely smeared as being purely political. Similarly, the European Court of Justice and the European Court of Human Rights work closely with domestic actors, in particular national authorities and elites that includes publicity and education campaigns, as well as invitations to national judges to seminars, dinners, and regular visits to their international chambers. ${ }^{167}$ The professional manner in which they conduct their activities contributes in large part to their ability to augment perceptions of being apolitical. 168

165. Allison Marston Danner \& Jenny S. Martinez, Guilty Associations: Joint Criminal Enterprise, Command Responsibility, and the Development of International Criminal Law, 93 CAL. L. REV. 75, 98 (2005) (noting that there is no oversight body established to oversee the development of ICL).

166. The author noted this reaction to her presentation of this proposal at the symposium entitled, International Justice in the 21st Century: The Law and Politics of the International Criminal Court, held at the John Marshall Law School on April 23, 2010. See also Hans-Peter Kaul, International Criminal Court: Current Challenges and Perspective, 6 WASH. U. GLOBAL STUD. L. REV. 575, 579 (2007) (emphasizing that ICC needs to be "a purely judicial, objective, neutral and non political institution.").

167. Turner, Nationalizing International Criminal Law, supra note 136, at 30.

168. While scholars debate whether the ICC risks being politicized, I adopt the view that in reality the ICC is necessarily operating in a political context and its decisions have political consequences, and so it perhaps is more effective to acknowledge that reality and then contemplate manners to assure its professionalism and objectivity to the extent possible. Mark Goodale \& Kamari Maxine Clarke, Introduction: Understanding the Multiplicity of Justice in MIRRORS OF JUSTICE: LAW AND POWER IN THE POST-COLD WAR ERA, 
Similarly, the ICC could encourage States Parties to implement the provisions of the Rome Statute as part of a general strategy to strengthen the national jurisdiction to assure that it can "efficiently investigate and prosecute the serious crimes prohibited in the Statute." 169 An expansive policy of proactive complementary would realize that assisting states in this process goes to the heart of its mission. Indeed, the OTP has already formed pacts with international associations of states like the Organization of American States and the African Union, and so in essence, it would merely be removing a bureaucratic level to increase the effectiveness of its work. ${ }^{170}$ For example, the Jurisdiction, Complementarity and Cooperation Division (JCCD) of the OTP may assume this type of role, which given limited resources does not need to be as extensive as perhaps the UNHRC, but could at least begin with something like an impunity index that requires States Parties to report their progress periodically. In fact, as early as 2003, Amnesty International (AI) suggested that the OTP adopt an "anti-impunity index." 171 This undertaking would require the OTP to maintain a database of factors that contribute to combating impunity including ratification of the Rome Statute; implementing legislation; and reporting on crimes committed in state and non-state parties, the number of national criminal investigations opened and completed, sentences fully served, orders of reparations, and amnesties. ${ }^{172}$

Significantly, while the ICC has yet to fully embrace the AI recommendations, it nevertheless may be moving in the direction of taking a more active role in monitoring state implementation of Rome Statute norms. In a report by the Bureau of Cooperation at

supra note 27, at 13 (Kamari Maxine Clarke \& Mark Goodale eds., 2009) (referring to "essentially and crucially political" nature of ICC).

169. Yang, supra note 51, at 123.

170. Philippe Kirsch, The Role of the International Criminal Court in Enforcing International Criminal Law, 22 AM. U. INT'L L. REV. 539, 546 (2007) (noting that OTP established agreement with Organization of American States); Olugbuo, supra note 55, at 128 (discussing Memorandum of Understanding negotiated by O'TP with African Union to assure ratification by all African states to the Rome Statute; Olugbuo noted that MOU had not been signed nor had an AU department been designated for this process).

171. Summary of recommendations received during the first Public Hearing of the Office of the Prosecutor, available at http://145.7.218.139 /iccdocs/asp_docs/library/organs/otp/ph/ph1_conclusions.pdf; Christopher Keith Hall, Suggestions concerning International Criminal Court Prosecutorial Policy and Strategy and External Relations, available at http://www.icccpi.int/iccdocs/asp_docs/library/organs/otp/hall.pdf; Informal expert paper: The principle of complementarity in practice, available at http://www.icccpi.int/iccdocs/asp_docs/library/organs/otp/complementarity.pdf [hereinafter Informal expert paper].

172. Informal expert paper, supra note 171, at 4; Perrin, supra note 30 , at 321. 
the Seventh Session of the Assembly of States Parties, a new priority included the "[d] evelopment of a framework for action for the adoption of national legislation pursuant to article 88 of the Rome Statute."173 In fact, the Bureau had begun to compile a record "of all available information on the current situation regarding States Parties' adoption of implementing legislation and of legislation on investigation and prosecution, as well as on ratification of the Agreement on the Privileges and Immunities of the Court."174 The purpose is to be able to identify what needs to be done to aid states in drafting legislation in furtherance of the Rome Statute. ${ }^{175}$ Indeed, OTP policy papers contemplate "actively remind[ing] States of their responsibility to adopt and implement effective legislation and encourage them to carry out effective investigations and prosecutions." 176

Arguably, the simple attention paid by the ICC and the need for States Parties to report this information could influence the movement toward the final goal of full harmonization with the Rome Statute. In this situation, the ICC would engage with states despite the absence of any potential Article 17 case, but still work within its mandate to help achieve its overarching mission of combating impunity. This work may occur through the JCCD, which is "tasked with fulfilling several roles including catalyst and monitor" but whose current focus follows the more narrow approach to complementarity and focuses on admissibility issues of potential post-2002 cases. 177 The impact of this expanded role could have potentially been seen in the case of Peru in three important ways: assuring willing and able national jurisdictions, assuring the uniformity of the development of international criminal law, and lending moral support for local actors mobilized to combat impunity.

\section{A. Assuring Willing and Able National Jurisdictions}

This expanded proactive role could have played an important role in assuring the impetus started by Peru's transitional government to harmonize its national laws with the Rome Statute. The JCCD may have not only engaged Peru's local politicians better, but also could have held the state to account for its failed

173. ICC-ASP, Report of the Bureau of Cooperation, 3 (Oct. 29, 2008) [hereinafter Assembly].

174. Id.

175. Id. at 4; ICC-ASP, Report of the Bureau on Ratification and Implementation of the Rome Statute and on Participation in the Assembly of States Parties, ICC-ASP/5/26 (Nov. 17, 2006).

176. ICC-OTP, The principle of complementarity in practice, ICC-OTP 2003, available at http://www.icc-cpi.int/iccdocs/doc/doc654724.PDF; Assembly, supra note 173 , at 5 .

177. Perrin, supra note 30 , at 320. 
initiative. For example, the Peruvian government publicly claimed to be making progress regarding its obligations under the ICC in Periodic Reviews to the United Nations Human Rights Council as recent as 2008. Arguably, had the JCCD taken more active interest in Peru's national harmonization process, it could have perhaps brought to light the gap between the government's public declarations and the reality of its failure to fully harmonize its domestic system with the Rome Statute. It could have also helped educate the various local political factions regarding the positive consequences of implementing harmonizing legislation (that is, it would actually protect members of their political parties from future prosecution by the ICC for alleged crimes occurring before 2002).

Peru is not the only State Party to encounter difficulties in national harmonization processes. Benson Chinedu Olugbuo, a former coordinator for the Coalition for the International Court, describes similar challenges within many of the African states that ratified the Rome Statute, attributing the delay to lack of technical skill coupled with the lack of political will. ${ }^{178}$ Olugbuo proposes that "if the ICC is to have the desired result of developing criminal justice systems in Africa, it is the role of the NGOs and government agencies to ensure that synergies of cooperation are developed through the effective implementation of the provisions of the Treaty of Rome in national legislations." 179

Certainly, as seen in the case of Peru, NGOs play a central role in national settings for exerting pressure or providing guidance and assistance with regard to implementing international criminal law. Indeed, people concerned about the potential risk to the ICC's apolitical neutrality and thus legitimacy, often propose that NGOs should bear the burden of directly working with States Parties to harmonize with Rome Statute obligations. ${ }^{180}$ NGOs already play a critical role not only in the realization of the ICC's mission, but the continued on-theground work to actualize a Rome system of justice. ${ }^{181}$ Yet due to the fact that NGOs can at times be perceived as very political and self-interested, they will not always offer the same type of moral authority that comes from an international organization like the Court. ${ }^{182}$

178. Olugbuo, supra note 55, at 112.

179. Id. at 125 .

180. Kirsch, supra note 170 , at 546.

181. Zoe Pearson, Non-Governmental Organizations and the International Criminal Court: Changing Landscapes of International Law, 39 CORNELL INT'L L.J. 243, 244 (2006).

182. Andrea E. K. Thomas, Nongovernmental Organizations and the International Criminal Court: Implications of Hobbes' Theories of Human Nature and the Development of Social Institutions for Their Evolving Relationship, 20 EMORY INT'L L. REV. 435, 469 (2006). 
Here, the ICC as an international body would use "iterative interactions" to drive the more subtle process of socializing states to international norms. ${ }^{183}$ The potential "norm leadership" of international tribunals on national reform can be seen in the impact of the International Criminal Tribunal for the Former Yugoslavia's Completion Strategy, which included outreach to build local capacity and transfer "best practices" so national courts could handle trials dealing with international crimes. ${ }^{184}$ Similarly, the ICC would be well positioned to begin influencing state behavior and ultimately compliance with the Rome Statute obligations, thus contributing to good governance. ${ }^{185}$

\section{B. Assuring Uniformity in the Development of International Criminal Law}

Similar to the engagement described above, the JCCD could have also issued pronouncements on certain legal questions related to the Fujimori trial as a way to "more fully articulat[e] the standards for genuine prosecutions by national governments" as well as contribute to the progressive codification of international criminal law. ${ }^{186}$ For example, international criminal law consists of a "distinct body of international legal rules" such as the applicability of universal jurisdiction, the bar to statutes of limitations, amnesty and pardon, the rejection of due obedience defense and the doctrine of command responsibility. ${ }^{187}$ Arguably, international criminal law also bars pardons for acts determined to be international crimes even if they are permissible for ordinary crimes. ${ }^{188}$ Here, Broomhall notes that

the absence from national law of the prohibitions, defences, general principles and sentences set out in the statute could support a finding of admissibility by the Court on the grounds of inaction at the national level .... In such cases, the State would not be able to

183. This line of thought follows the scholarship that advances theories on how states come to comply with international obligations. Ryan Goodman \& Derek Jinks, How to Influence States: Socialization and International Human Rights Law, 54 DUKE L.J. 621 (2004); Anne-Marie Slaughter \& William Burke-White, The Future of International Law is Domestic (or the European Way of Law), 47 HARV. INT'L L.J. 327 (2006).

184. William Burke-White, The Domestic Influence of International Criminal Tribunals: The International Criminal Tribunal for the Former Yugoslavia and the Creation of the State Court of Bosnia \& Herzegovina, 46 CoLuM. J. TRANSNAT'L L. 279, 340 (2008) [hereinafter Burke-White, The Domestic Influence of International Criminal Tribunals].

185. See id. at 289 (pointing out that impact of international courts on domestic governance remains understudied).

186. Burke-White, Complementarity in Practice, supra note 73, at 586.

187. Kleffner, supra note 7, at 98 .

188. Anees Ahmed \& Merryn Quayle, Can Genocide, Crimes Against Humanity and War Crimes Be Pardoned or Amnestied?, 79 AMICUS CURIAE 15 (2009). 
impose criminal responsibility on acts criminal under the Statute, resulting in de facto impunity. ${ }^{189}$

With regard to Peru, one pressing concern in the Fujimori case relates to the possibility of his being pardoned, especially if his daughter is elected president in 2012 , which at the time of this writing stands as a definite possibility. Significantly, the lack of clarity on the status of pardons in the Rome system of justice constitutes one of "the greatest weakness" of the complementarity regime. ${ }^{190}$ Similar to the ordinary crimes issue discussed above, the topic of pardons also provokes a divergence of academic opinions without yet arriving at consensus. ${ }^{191}$ Yet the Fujimori trial now sets a precedent in international criminal law regarding these legal issues, and arguably may impact the ICC's future deliberations, or alternatively, will stand as an anomaly within international criminal law should the ICC interpret these pardon issues differently. ${ }^{192}$

This potential outcome relates to the pressing concerns related to the fear of fragmentation in international criminal law, which depends on the disparate and uncoordinated efforts of international, hybrid, and national courts to slowly develop a solid jurisprudence for this relatively new body of law. ${ }^{193}$ Certainly, the OTP itself has publicly declared that it will no longer be neutral about national judicial actions, but rather endorses them and promotes them "where possible."194 Along these lines, Burke-White suggests that the OTP

may wish to develop and disseminate clear standards and best practices for the domestic prosecution of international crimes. Such standards and codes of best practices are already being used in other areas of international law ... [to] offer a non-legally binding means of encouraging genuine domestic prosecutions by giving national governments guidance around which they can structure

189. Bruce Broomhall, The International Criminal Court: Overview and Cooperation with States, in ICC RATIFICATION AND NATIONAL IMPLEMENTING LEGISLATION at 81 (1999).

190. El Zeidy, supra note 42 , at 944.

191. Id.; Ahmed \& Quayle, supra note 188, at 15.

192. Freeland, supra note 125 , at 45.

193. Radosavljevic, supra note 100 , at 148 . See generally Martti Koskenniemi \& Paivi Leino, Fragmentation of International Law? Postmodern Anxieties, 15 LEIDEN J. INT'L L. 553 (2002) (offering an overview of the concern with regard to the lack of coherence in the interpretation of international law). But see Alexander K.A. Greenawalt, The Pluralism of International Criminal Law, $86 \mathrm{IND}$. L. J. (forthcoming 2011) (offering alternative view on different tiers of international criminal law that in fact accommodate local pluralism).

194. ICC-OTP, Paper on Some Policy Issues before the Office of the Prosecutor (Sept. 2003) available at http://www.amicc .org/docs/OcampoPolicyPaper9_03. pdf. 
their own activities. ${ }^{195}$

In fact, the idea of promoting a more engaged court reflects a new trend that sees international tribunals adopting outreach and capacity building programs to complement their more traditional juridical work. ${ }^{196}$ Even if the ICC is not a human rights monitoring mechanism, it still should have a vested interest in overseeing the development of an effective Rome system of justice if it is to truly realize its mandate of combating impunity.

Yet importantly, this role need not be restricted only to those domestic trials that potentially fall within Article 17 jurisdiction, but rather, would be available to all States Parties. The ICC already appears to be moving in this direction with the creation of its "matrix system," which offers legal research and reference tools on specific procedural and substantive issues. ${ }^{197}$ While these resources still take the narrow focus of jurisdictional issues, they nonetheless demonstrate the ICC's capacity for standard setting in a more general, informative manner. The Case Matrix is part of a larger set of "Legal Tools" offered by the ICC that "provides the general public with free access to the Legal Tools Database of basic legal information in international criminal law . . ."198 The initiative is described as "[a] project developed by the International Criminal Court being made available to governments, judges, prosecutors, defence counsels, NGOs and other around the world in the spirit of complementarity of the

195. Burke-White, supra note 4 , at 93 .

196. The International Criminal Tribunal for the Former Yugoslavia created a capacity building and outreach program that includes training on the rule of law. See generally ICTY OUTREACH, http://www.icty.org/sections/Outreach (last visited Aug. 2, 2010). See also Burke-White, The Domestic Influence of International Criminal Tribunals, supra note 184, at 279 (describing outreach programs instituted by the ICC). Similarly, the Special Court for Sierra Leone created an outreach and capacity building program. THE SPECIAL COURT FOR SIERRA LEONE, http://www.sc-sl.org/ABOUT/CourtOrganization/TheRegistry/ OutreachandPublicAffairs/tabid/83/Default.aspx (last visited Aug. 2, 2010). For more information about this program, see Scott Worden \& Emily Wann, Special Court of Sierra Leone Briefing: The Taylor Trial and Lessons from Capacity Building and Outreach, U.S. INSTITUTE OF PEACE (Aug. 2007), $\mathrm{http}$ ://www.usip.org/resources/special-court-sierra-leone-briefing-taylor-trialand-lessons-capacity-building-and-outreac.

197. ICC, ICC Legal Tools: Case Matrix, Elements Commentary, Proceedings Commentary and Means of Proof Document, http://www.icccpi.int/NR/rdonlyres/69B03FCB-ED50-4177-A785-EA71B309CB7F/0/ICCLegal Tools_ENG.pdf (last visited Aug. 2, 2010).

198. ICC, What are the ICC legal tools?, http://www.legal-tools.org/en/whatare-the-icc-legal-tools/ (last visited Aug. 2, 2010). See also ICC, The Case Matrix, http://www.icc-cpi.int/NR/rdonlyres/58958352-4379-46AB-81E861A7D85418D2/0/ICCCaseMatrix_ENG.pdf (last visited Aug. 2, 2010) (displaying software for case management of complex international prosecutions). 
Court."199

The implicit understanding of this expansive sphere of influence is that even those cases directly impact the development of international criminal law, and thus the mandate of the ICC. Notably, one important outcome of these outreach programs is to also raise public awareness and "public consciousness" regarding the importance and binding nature of international criminal law, and as a consequence creating a global expectations that impunity will not be tolerated. 200

Burke-White also suggests that the desire to assure uniformity in international criminal law might justify "a national court submitting a question of law to the ICC."201 He suggests as a model the certified question process used to petition U.S. federal courts to ascertain unsettled questions of state law or the interpretative questions sent to the European Court of Justice to assure uniformity in EU law among member states. Or one may consider the role of the Inter-American Court of Human Rights, which has the ability to take requests for advisory opinions on questions of law under the American Convention on Human Rights which are not connected to a particular case. ${ }^{202}$ An additional approach could occur through inter-judicial networks that encourage exchanges, dialogue, and meetings between national and international courts that could lead to the sharing of best practices, advice and guidance. ${ }^{203}$ Indeed, the OTP has even suggested this type of interaction as part of its more positive complementarity approach. ${ }^{204}$ This type of "vertical process" can "spur a productive dialogue about the substance and procedure of prosecutions of international crimes"205 and eventually allow for domestic "internalization" of international norms. ${ }^{206}$

199. ICC, Legal Tools Project, http://www.legal-tools.org/fileadmin/user upload/Legal_Tools_V._Jul09.pdf (last visited Aug. 2, 2010). The quoted material is right at the top of the "brochure."

200. Freeland, supra note 125 , at 71 .

201. Burke-White, A Community of Courts, supra note 71, at 94.

202. Thomas Buergenthal, The Advisory Practice of the Inter-American Human Rights Court, 79 A.J.I.L. 1 (1985).

203. Jenia Iontcheva Turner, Transnational Networks and International Criminal Justice, 105 MICH. L. REV. 985, (2007); Kal Raustiala, The Architecture of International Cooperation: Transgovernmental Networks and the Future of International Law, 43 VA. J. INT'L L. 1 (2002).

204. See Informal expert paper, supra note 171, at 5-6 (recommending that ICC provide information, evidence, technical expertise and training to national authorities).

205. Turner, supra note 136 , at 35 .

206. Harold Hongju Koh, How is International Human Rights Law Enforced?, 74 IND. L.J. 1397, 1406 (1999). 


\section{Lending Moral Support for Local Actors Mobilized to Combat Impunity}

The type of ICC engagement described above could have lent the more subtle type of moral support for local actors in Peru engaged in a transitional justice project not only intent upon reforming their country to align itself with international norms, but also in the process of cultivating the 'glue' that will ultimately hold together the Rome system of justice: the attitudes and demands for challenging cultures of impunity. In theory, prosecutions for international crimes both at the international and national level should help to build an "accountability cascade"through which the expectations of all the world's citizens for accountability will become the norm-overcoming the legacy of a "previous and pervasive impunity cascade in which order and accountability simply broke down . . .."207 This "cascade" refers to one of the

most important and difficult challenges confronting a post-conflict society is the reestablishment of faith in the institutions of the state. Respect for the rule of law in particular, implying subjugation to consistent and transparent principles under state institutions exercising a monopoly on the legitimate use of force, may face special obstacles. In territories where state institutions existed as tools of oppression, building trust in the idea of the state requires a transformation in the way such institutions are seen. 208

Complicating matters, transitional justice settings always run the risk of the old manipulative tendencies to obstruct progressrequiring a counterbalancing population to demand accountability. Ironically, the members of society who must be vigilant to push forward reform despite these old tendencies of the power hold-outs to push against change are the same people disempowered by the previous system. ${ }^{209}$ Here is where the perceived interest of an international institution like the ICC can empower local actors to organize and lobby for change and appropriate the norms of international law to serve their search for justice. ${ }^{210}$ In essence,

207. Jane E. Stromseth, Pursuing Accountability for Atrocities after Conflict: What Impact on Building the Rule of Law?, 38 GEO. J. IN'T'L L. 251, 256 (2006). 208. Simon Chesterman, Rough Justice: Establishing the Rule of Law in Post-Conflict Territories, 20 OHIO ST. J. ON DISP. RESOL. 69, 69 (2005) (emphasis omitted).

209. Lisa J. Laplante \& Miryam Rivera, The Peruvian Truth Commission's Mental Health Reparations: Empowering Survivors of Political Violence to Impact the Public Health Policy, 9 (2) HEALTH \& HUM. R'S. INT'L J. 136, 137 (2006).

210. Anthropologist Sally Engle Merry offers important ethnographic research that demonstrates the importance of grassroots movements "vernacularizing" international norms into local settings. Sally Engle Merry, Transnational Human Rights and Local Activism: Mapping the Middle, 108 AMER. ANTHROPOLOGIST 38 (2006). 
the internalization of international norms through a social and political process plays a critical-if often overlooked-role in domesticating international rights norms. ${ }^{211}$ More recent scholarship on why nation-states comply with international obligations recognizes the organic process of generating compliance with and enforcement of international law. ${ }^{212}$

Adopting a socio-legal lens, Jacqueline Kiggundu explores this phenomenon in the case of Uganda, arguing that the ICC can - set a positive momentum for sustained change-a "ripple effect."213 Specifically, the ICC's indictments for sexual violence opened spaces for women in Uganda to speak on the need to "change existing laws, policies, and practices relating to crimes of sexual violence," and in particular to harmonize domestic law with international standards. ${ }^{214}$ In this way, the ICC became "a political tool to cultivate national responses, rather than as a rigid enforcement mechanism." 215 Thus, the ICC and the "power of complementarity" can be understood to be much more than a simple last-resort court for failed domestic prosecutions. Rather, the ICC does not even need to hear a case to shift social and political perceptions so as to permit the type of cultural changes and norm creation needed for its overarching aim of combating impunity. ${ }^{216}$

Importantly, Kiggundu suggests a modest role of the ICC in this social transformation: "While the ICC can encourage this shift through awareness campaigns and consultative meetings with affected communities, it is likely that a total revision will take time and concerted indigenous activism."217 In this way, the ICC acts as a socio-psychological catalyst of sorts. Interaction, dialogue,

211. See Sally Engle Merry, Beyond Compliance: Toward an Anthropological Understanding of International Justice, in MIRRORS OF JUSTICE: LAW AND POWER IN THE POST-COLD WAR ERA, supra note 26, at 30 (Kamari Maxine Clarke \& Mark Goodale eds., 2009) (referring to propositions of TOM TYLER, Why PEople Obey The LAW (Princeton Univ. Press, 2d ed. 2006) (1990)).

212. Harold Hongju Koh, Transnational Legal Process, 75 NEB. L. REv. 181 (1996); Harold Hongju Koh, Why Do Nations Obey International Law?, 106 YALE L. J. 2599, (1997).

213. Jacqueline Kiggundu, How Can the International Criminal Court Influence National Discourse on Sexual Violence? Early Intimations from Uganda, 4 EYES ON THE ICC 45, 62 (2007).

214. Id. at 45,58 .

215. Id. at 63 . One concern Kiggundu raises is whether this politicization could reduce the legitimacy of the court. Yet using an analogy, people in many contexts, including the United States, often use reference to the legal system as a persuasive tool in negotiations. This political use does not diminish the independence and legitimacy of the courts which do not directly contribute to this activity.

216. Id. at 47,60 .

217. Id. at 60-61. 
mutual assistance, and communication ${ }^{218}$ between the OTP and States Parties allows the ICC's presence to be felt and perceived by the general population, especially if reported on by the media. ${ }^{219}$ As a result, the ICC with arguably minimal effort or interference could help shape "attitudes about international criminal law and the enforcement of violations of international humanitarian law" and raise "global expectations that those responsible for the perpetration of atrocities must be held to account."220 This hypothetical scenario exemplifies "the discursive processes through which political, moral, and ideological currents come together in a particular way in the presence (or absence) of particular international and transnational actors . . ."221

As I have explored elsewhere, the influence of international bodies on domestic attitudes should not be underestimated in transitional justice settings. ${ }^{222}$ As a "respected voice of authority," their messages have great impact and serve the expressivist function of gelling local societal values. ${ }^{223}$ The power of the modest interventions can be seen in the case of Dutch prosecutors winning the conviction of arms dealers to the Middle East and Africa, and crediting their initiative to statements made by the OTP encouraging the investigation of the "criminal business" of war. Significantly, one of these cases concerned criminal acts occurring before 2002, and thus, would never be heard by the ICC. ${ }^{224}$

218. Stahn, supra note 67 , at $99-100$.

219. For more discussion on the important role of media in transmitting information in transitional justice settings and its contribution to normmaking see Lisa J. Laplante and Kelly Phenicie, Media, Trials and Truth Commissions:'Mediating' Reconciliation, in Peru's Transitional Justice Process, INT'L J. TRANSITIONAL JUST. (forthcoming 2010).

220. McCormack, supra note 1, at 26.

221. Goodale \& Clarke, supra note 168 , at 12 .

222. See Laplante, supra note 106 (exploring impact of Inter-American Court of Human Rights in shaping attitudes and ultimate direction of Peru's Transitional Justice experience).

223. See Keller, supra note 98 , at 274 (referring to work of Diane Marie Amann, Group Mentality, Expressivism, and Genocide, 2 INT'L CRIM. L. REV 93, $116(2002))$.

224. See Marlise Simons, Holding Arms Dealers Accountable at Home, INT'L HERALD TRIB., May 3, 2006, http://www.iht.com/articles/2006/05/02/ news/ha-

gue.php?page (noting that prosecutions of Frans van Anraat and Guus van Kouwenhoven, while a Dutch initiative, were prompted in part by presence in Hague of ICC and Prosecutor's expressions of hope that national jurisdictions would join ICC in investigating "criminal business" of war). Dutch businessman Frans van Anraat was sentenced to seventeen years in prison for selling chemicals to Saddam Hussein used in poison gas weapons that killed Kurdish villagers. Openbaar Ministerie/Frans van Anraat, Gerechtshof'sGravenhage, BA 4676, Judgment in Criminal Proceedings Against Van Anraat, Court of Appeal in The Hague (Neth.) (May 9, 2007) (English translation of judgment available at http://zoeken.rechtspraak.nl/resultpage. aspx?snelzoeken=true\&searchtype=ljn\&ljn=BA6734\&uljn=BA6734). 
Borrowing from another international-domestic context, the ICTY took part in public events that helped to "enhance the perceived legitimacy" of domestic courts poised to assume the work of the international tribunal. 225

This proposed view for interpreting the ICC's role gains support from legal and social science scholars who understand that simply holding a criminal trial does not guarantee the societal shift of perceptions and consciousness that must accompany the building of a culture of rights. ${ }^{226}$ Instead, contextual realities challenge norm creation. It is cautioned that "[p]lanting a [constitutional] proposition in a different cultural, historical, or traditional context may lead to results quite different from those one finds in the country from which the proposition was borrowed." 227 A formalistic approach to post-conflict reconstruction overlooks the need for "norm creation" which is something that does not exist beyond culture. 228 Thus, simply conducting standard procedures like criminal trials or creating formal legal structures like new penal codes does not automatically create the culturalbuy-in that internalizes these values into a constituency accustomed to living without the rule of law. ${ }^{229}$ In its substantive sense, the rule of law is a culture, yet this consideration and its implications for "the complex processes by which cultures are created and changed" often goes overlooked. ${ }^{230} \mathrm{It}$ is a process that entails "a mental transformation as much as a political one." 231

At essence, the mission of the ICC must confront this type of cultural shift given the stark reality of global impunity and the formidable challenge of defying perceptions of that reality to create a global commitment to combat impunity. Indeed, early writings

225. Burke-White, The Domestic Influence of International Criminal Tribunals, supra note 184, at 342.

226. Goodale \& Clarke, supra note 168 , at 5 .

227. A.E. Dick Howard, The Indeterminancy of Constitutions, 31 WAKE FOREST L. REV. 383, 403 (1996).

228. Rosa Ehrenreich Brooks, The New Imperialism: Violence, Norms, and the Rule of Law, 101 MrCH. L. REv. 2275, 2285 (2003).

229. While this perspective assumes some core minimum of conditions to assure the rule of law, it is couched with the sensibility offered by a recent line of scholarship cautioning the imposition of formalized prosecutions as the only approach to justice. Instead, a new challenge for the ICC will be figuring out its appropriate role in a complex world of legal pluralism. KAMARI MAXINE Clarke, Fictions of Justice: The InTERnational CRIMINal Court and THe Challenge of Legal PluRalism IN Sub-SaHARan AFrica (2009). In fact, the proposed interactive role of the ICC may better "demarcate the boundaries between fundamental international law norms, from which deviation is unacceptable, and issues on which deliberation and diversity ... is welcome." Turner, Nationalizing International Criminal Law, supra note 136, at 41.

230. Brooks, supra note 228, at 2285.

231. Simon Chesterman, Rough Justice: Establishing the Rule of Law in Post-Conflict Territories, 20 OHIO ST. J. ON DISP. RESOL. 69, 96 (2005). 
on the need to form an ICC alluded to the idea that the Court would promote a "culture of accountability, enforcement, and punishment."232 Creating a global commitment to combating impunity entails the "construction of a complete worldview" that includes the evolution of subjective meaning. ${ }^{233}$ Along these lines the Chief Prosecutor Moreno-Ocampo recognized that the "formation of a particular transnational normative sensibility" and the establishment of any formal operationalization of international criminal law, there needs to be "a diffuse but systematically critical engagement" somewhat akin to a "global university." 234 Consistent with this vision, policy papers issued by the OTP envision the ICC to encourage both States Parties and other states to carry out consistent and rigorous national proceedings. The ICC proposes to accomplish this effect through its encouragement and co-operation; through the prospect of the ICC exercising jurisdiction; through its own exemplary and standard-setting proceedings; and through its moral presence, which will shape perspectives and strengthen resolve on the need for accountability. ${ }^{235}$

While a daunting proposition, arguably cultural transformation begins with local actors becoming aware of the ICC, which can only occur when the presence of the ICC can be felt (and its concern perceived) by people at ground level.

\section{CONCLUSION}

The broad interpretation of the complementarity principle offered in this article would free the ICC to set a path for achieving a more unified sphere of influence. While the opportunity to apply this more expansive approach in Peru was missed, we can still use the experience during the Fujimori trial to gain insight as to what this type of relationship might look like in future cases.

Ultimately, this international-national arrangement falls in line with contemporary thinking that international criminal law needs to be decentralized. This standard, of course, would include all domestic prosecutions and not only those that could potentially trigger the ICC's jurisdiction. A more expansive role of the ICC would assure the consistent and uniform development of international criminal law, and a more effective Rome system of justice. Consistent with his general proposal for proactive

232. Zoe Pearson, Non-governmental Organizations and the International Criminal Court: Changing Landscapes of International Law, 39 CORNELL INT'L L.J. 243, 252 (2006).

233. Paul W. Kahn, The Cultural Study of LaW: Reconstructing LEGAL SCHOLARSHIP 2 (2000).

234. The Prosecutor's ideas are summarized in Goodale \& Clarke, supra note 168 , at 4.

235. Informal expert paper, supra note 171, at 4-5. 
complementarity, Burke-White reminds us,

the ICC is not merely a significant new international mechanism for accountability. Nor are the complementarity provisions of the Rome Statute merely means for determining when cases will be admissible before the Court. Rather, the ICC and the complementarity regime are embedded in a system of interactions with national institutions that have the potential to collectively enhance the prospects for accountability and good governance at the national as well as supranational levels. ${ }^{236}$

Significantly, recent policy statements issued by the OTP indicate that it may be more fully embracing the concept of "positive complementarity" that goes beyond the strict admissibility test and instead moves toward "a proactive policy of cooperation aimed at promoting national proceedings." ${ }^{237}$ As the OTP explains,

[w]ith the complementarity principle, much of the work done to achieve the goals of the Statute may take place in national judiciary around the world. Thus, the number of cases that reach the Court is not a positive measure of effectiveness. Genuine investigations and prosecutions of serious crimes at the domestic level may illustrate the successful functioning of the Rome system. ${ }^{238}$

While time will tell how this policy will play out in practice, it nonetheless reflects an important shift in the official understanding of complementarity: one that expands the ICC's sphere of influence to assure a more efficient and effective attack on global impunity.

236. Burke-White, Complementarity in Practice, supra note 73, at 589-90.

237. ICC, Office of the Prosecutor, Prosecutorial Strategy 2009-2010 (Feb. 1, 2010) available at http://www.icc-cpi.int/NR/rdonlyres/66A8DCDC-3650-4514AA62-D229D 1128F65/281506/OTP ProsecutorialStrategy20092013.pdf.

238. Id. at If 79 . 